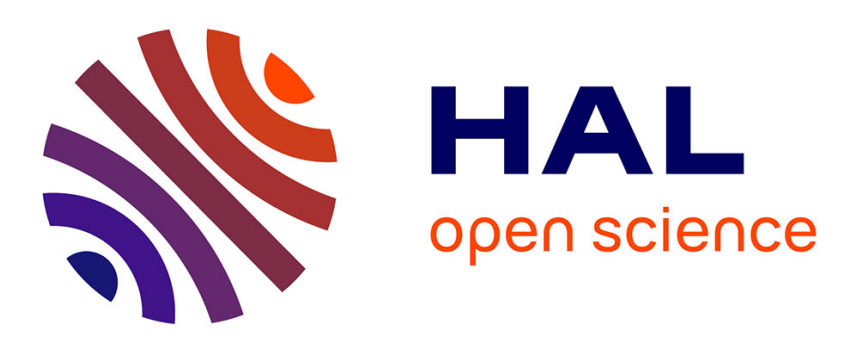

\title{
Aromatase, estrogen receptors and brain development in fish and amphibians
}

\author{
Pascal Coumailleau, Elisabeth Pellegrini, Fátima Adrio, Nicolas Diotel, Joel \\ Cano-Nicolau, Ahmed Nasri, Colette Vaillant, Olivier Kah
}

\section{- To cite this version:}

Pascal Coumailleau, Elisabeth Pellegrini, Fátima Adrio, Nicolas Diotel, Joel Cano-Nicolau, et al.. Aromatase, estrogen receptors and brain development in fish and amphibians. Biochimica et Biophysica Acta - Gene Regulatory Mechanisms , 2015, Nuclear receptors in animal development, 1849 (2), pp.152-162. 10.1016/j.bbagrm.2014.07.002 . hal-01102449

\section{HAL Id: hal-01102449 \\ https://hal.science/hal-01102449}

Submitted on 12 Jan 2015

HAL is a multi-disciplinary open access archive for the deposit and dissemination of scientific research documents, whether they are published or not. The documents may come from teaching and research institutions in France or abroad, or from public or private research centers.
L'archive ouverte pluridisciplinaire HAL, est destinée au dépôt et à la diffusion de documents scientifiques de niveau recherche, publiés ou non, émanant des établissements d'enseignement et de recherche français ou étrangers, des laboratoires publics ou privés. 
Aromatase, estrogen receptors and brain development in fish and amphibians

Pascal Coumailleau ${ }^{1^{*}}$, Elisabeth Pellegrini ${ }^{1^{*}}$, Fátima Adrio ${ }^{2}$, Nicolas Diotel $^{3}$, Joel Cano-Nicolau ${ }^{1}$, Ahmed Nasri ${ }^{1}$, Colette Vaillant ${ }^{1}$, and Olivier Kah ${ }^{1}$

${ }^{*}$ Equal contribution

${ }^{1}$ Research Institute in Health, Environment and Occupation

INSERM U1085, SFR Biosit

Université de Rennes 1

Campus de Beaulieu

35042 Rennes cedex, France

\section{2Área de Bioloxía Celular}

Departamento de Bioloxía Celular e Ecoloxía.

Campus Vida. Universidade de Santiago de Compostela.

15782 Santiago de Compostela, Spain

${ }^{3}$ Groupe d'Etude sur l'Inflammation Chronique et l'Obésité (GEICO EA 4516)

Faculté des Sciences et Technologies - 15 av René Cassin - BP 7151

97715 Saint Denis - La Réunion - France

1192 lines

Address for correspondence:

Dr. Olivier Kah

Research Institute in Health, Environment and Occupation

INSERM U1085, SFR Biosite

Université de Rennes 1

Campus de Beaulieu

35042 Rennes cedex

France

tel: +33223236765

fax: +33223236794

olivier.kah@univ-rennes1.fr 


\begin{abstract}
Estrogens affect brain development of vertebrates, by impacting activity and morphology of existing circuits, but also by modulating embryonic and adult neurogenesis. The issue is complex as estrogens can not only originate from peripheral tissues, but be locally produced within the brain itself due to local aromatization of androgens. In this respect, teleost fishes are quite unique because aromatase is expressed exclusively in radial glial cells, which represent pluripotent cells in the brain of all vertebrates. Expression of aromatase in the brain of fish is also strongly stimulated by estrogens and some androgens. This creates a very intriguing positive auto-regulatory loop leading to dramatic aromatase expression in sexually mature fish with elevated levels of circulating steroids. Looking at the effects of estrogens or anti-estrogens in the brain of adult zebrafish showed that estrogens inhibit rather than stimulate cell proliferation and newborn cell migration. The functional meaning of these observations is still unclear, but these data suggest that the brain of fish is experiencing constant remodelling under the influence of circulating steroids and brain-derived neurosteroids, possibly permitting a diversification of sexual strategies, notably hermaphroditism. Recent data in frogs indicate that aromatase expression is limited to neurons and do not concern radial glial cells. Thus, until now, there is no other example of vertebrates in which radial progenitors express aromatase. This raises the question of when and why these new features were gained and what are their adaptive benefits.
\end{abstract}

Key words: estrogen, estrogen receptor, aromatase, cyp19a1, neurogenesis, radial glia, plasticity, zebrafish, teleosts, $\mathrm{X}$. laevis 


\section{Introduction}

In 1943, Edward A. Doisy (1893-1986) received the Nobel prize for his discovery of the chemical nature of vitamin K, but Doisy and his colleagues should also be remembered as the discoverers of estriol, estrone and estradiol [1]. Estradiol is a cholesterol derivative mostly known for its actions on the œstrus cycle and the maintenance of female sexual characters. Estradiol was originally considered as a female hormone [1], until it was found, unexpectedly at the time, that E2 was present in the urine of the stallion [2]. This finding set the stage for the discovery that estrogens in fact derive from androgens thanks to the action of cytochrome P450 aromatase, the only enzyme capable of aromatizing the A ring of C19 androgens to convert them into C18 estrogens. With the exception of suidae, in which there are 5 aromatase genes (also named cyp19a1), most vertebrates have a single cyp19a1 gene whose tissue specific expression is driven by multiple aromatase promoters [3]. Apart from the gonads, aromatase is expressed in a large variety of tissues such as the bones, the skin, the adrenals, the adipose tissue, the fœtal liver, the placenta and some breast cancers. In addition, aromatase is also well expressed in the central nervous system of all vertebrates where it is supposed to play complex and still poorly understood roles [4-6].

Since the seminal work of Alfred Jost on the hormonal control of sex differentiation in the mammalian foetus [7] and the development of the aromatization hypothesis [8], our views on aromatase and estrogen functions in the brain are largely influenced by the mammalian literature. In rodents, there is considerable evidence that the masculinization effects of testosterone on the organization of malespecific circuits are caused by aromatization and are in fact mediated by estradiol. The molecular and cellular mechanisms underlying those estrogenic effects have been thoroughly studied and involve complex age-, sex- and region-specific actions on cell proliferation, apoptosis and differentiation [9-11]. This provides evidence that, at least in this case, estrogens can modulate neurogenesis to cause irreversible sexual dimorphism of some brain structures. In addition, over the last ten years, a number of studies reported potential effects of estrogens and xeno-estrogens, notably bis-phenol $A$, in either embryonic neurogenesis and/or in the adult neurogenesis in the hippocampus [12-16]. There has been already several excellent reviews dealing with the putative functions of aromatase in mammals or birds and the role of estrogens in modulating brain functions [11, 17-22]. On the other hand, a 
number of reports have shown that upon mechanical or chemical lesions, there is an up regulation of aromatase expression in either reactive astrocytes surrounding the lesions or in radial glial cells (RGCs) facing the lesions as shown in birds, suggesting that aromatase expression in cells of the astroglial lineage would be part of the mechanisms supporting brain repairs after lesion [11, 21, 23-28]. Thus aromatase can, under certain circumstances, be expressed in cells of the astrocyte lineage, notably under situation of brain repair, while it is admitted in mammals and birds that aromatase is expressed primarily in neurons [29, 30].

In contrast to estradiol, testosterone is usually perceived as a male hormone, but this is not the case in all vertebrates. In fish for example, a wealth of data have demonstrated that testosterone is present in the blood of both males and females [31, 32] and that fish have some particular non aromatizable androgens, such as 11-ketotestosterone that is found only in males and triggers male secondary sexual characters and sexual behavior [33]. Fish are also unique in that they exhibit an amazing sexual plasticity. They are the only vertebrates capable of total sex change, either naturally or upon hormonal treatment. Thus, the above-mentioned aromatization hypothesis probably does not apply to teleost fishes, but it is possible that this sexual plasticity is linked to some of the remarkable characteristics of aromatase expression and functions in the brain of teleost fish that will be reviewed in this article.

Teleost fishes offer an alternative model in which there is a clear neuroanatomical link between estrogen production in the brain and neurogenesis. Indeed, in teleost fishes, radial glial cells strongly express aromatase and the questions are to understand when and why this feature emerged during evolution. Whether this particular situation is found only in fishes or is also observed in basal tetrapods is unclear. Recently released information on frogs will also be examined in this review for evolutive and comparative purposes.

\section{1- Estrogen receptors, aromatase and radial glia in the brain of fish}

Teleost fish (Teleostei) represent one of three infraclasses of Actinopterygians, corresponding to the so-called ray-finned fishes. This is a highly diversified group that arose 280-250 millions years ago and comprises around 26,000 species in about 40 orders and that include most of the living fishes, including the economically-relevant species that are the topic of intense research. A major characteristic of these animals is that, compared to tetrapods, they experienced an additional whole genome 
duplication that took place early in the emergence of the group. As a result of this duplication, known as the $3 R$ [34], teleost fish have potentially twice as much genes than other vertebrates (2:4:8 rule). Although many of these duplicated genes have been lost during evolution, some of them are conserved and developed new or exaggerated functions.

\section{1- Estrogen receptors in teleost fishes}

The first estrogen receptor cloned in fish was that of the rainbow trout $[35,36]$, soon after the cloning of the human ERa (esr1) [37]. Compared with the mammalian $E R \alpha$, this rainbow trout ( $r$ ERa) of $65 \mathrm{kDa}$, named ERa short, exhibited at the $\mathrm{N}$ terminus a deletion of 45 amino acid residues corresponding to the $A$ domain. However, subsequently a longer ERa form of $71 \mathrm{kDa}$ was retrieved from an ovarian library [38, 39]. By S1 nuclease protection assays, it was shown that these two isoforms derived from two classes of mRNA generated by an alternative usage of two promoters. Consequently, these mRNA species differ in their 5'-untranslated region and the presence of an ATG in exon 2 a permits adding 45 residues at the $\mathrm{N}$-terminus of rtERa-long. Analysis of the transcriptional activities of these isoforms in a yeast cell system demonstrated that, in contrast with rtERa-long, rtERa-short exhibits a ligand-independent transactivation capacity representing $15-25 \%$ of the full-length receptor activity. Structural analysis of the AF1 function showed that as it is the case of the mammalian ERa, in the absence of ligand, the A domain of the rtERa-long interacts with the C-terminal region in the absence of ligand, causing inhibition of the AF1 activity located in the B domain [38, 39]. Studies in rainbow trout showed that the full-length ERa is expressed in liver, brain, pituitary, and ovary, whereas expression of the ERa short is restricted to the liver, demonstrating a tissue-specific expression of these two ERa isoforms [40].

Following these pioneer studies and the discovery of two estrogen receptors in mammals [41], it rapidly appeared that teleosts have not only one ERa, but also two ERß resulting from an ancient duplication [42, 43]. Zebrafish, probably the bestdocumented fish, has three ER, two ERß, ERß1 (esr2b), and ERß2 (esr2a) and one ERa (esr1). These three estrogen receptors bind estradiol with a high affinity within the $0.5-0.7 \mathrm{nM}$ range, similar to what has been observed in mammals [43]. They also have transactivation capacity on reporter genes bearing estrogen responsive element, with ERß2 exhibiting a little more efficiency than the other two receptors, starting at $10^{-12}-10^{-11} \mathrm{M}$. All three ERs are expressed in a wide variety of tissues including the 
brain [43].

One of the characteristics of ERa, at least in the liver, is its spectacular up regulation by its own ligand. This phenomenon has been first deciphered at the molecular level in the rainbow trout and is the basis for the strong induction of vitellogenin expression in the liver upon estrogenic modulation [35]. Such an up regulation of ERa is also observed in the brain, but the induction is much lower than what is observed in the liver [44].

\section{2 - Estrogen receptors in the brain of teleosts}

Estrogen receptor expression has been studied in detail in a limited number of species, in particular the rainbow trout $[45,46]$, the zebrafish $[43,47,48]$, the European sea bass $[49,50]$ and the medaka [51, 52]. As already documented in mammals, ERa is well expressed in the classical neuroendocrine regions of the brain such as the preoptic area and the mediobasal and caudal hypothalamus, whereas ERßs have a wider distribution in particular along the brain ventricles of the telencephalon and diencephalon. In the preoptic area and the mediobasal hypothalamus, it is very likely that the three receptors are expressed in the same cells (F. Adrio et al., unpublished). Antibodies against the fish estrogen receptors have been developed only in rainbow trout and they are limited to ERa. Although these antibodies permitted to obtain excellent stainings in line with the distribution of the mRNAs, they were rapidly exhausted due to low titer and a necessary purification enrichment step $[45,46]$. Due to the lack of good antibodies, the identity of cells bearing estrogen receptor expression is not entirely clear. However, there are evidences that ERa is expressed primarily in neurons, in particular in dopaminergic neurons of the preoptic region [53], GABA neurons [54], GnRH 3 neurons [52] and kisspeptin neurons [52, 55, 56]. Because expression of cyp19a1b, encoding aromatase $B$ in fish, is so strongly regulated by E2 through an ER dependent mechanism (see below), it would be expected to observe ER in the RGC. In fact, by increasing the sensitivity of the in situ hybridization techniques, through either amplification of the signal or using radioactive probes with longer exposure, it appears that ERß is likely expressed along the brain ventricles, notably in the telencephalon, preoptic area and mediobasal hypothalamus, but to much lower levels than in neurons of the preoptic area and hypothalamus (Figure 1).

\section{3 - Radial glia progenitors express aromatase in teleost fishes}


A striking feature of the brain of teleost fish is the fact that brain aromatase is massively expressed in radial progenitors of adult animals. Among vertebrates, teleost fish are unique in having two aromatase genes [57], which clearly derive from the whole genome duplication that occurred at the emergence of the teleost lineage [58]. One of these genes, cyp19a1a, encodes aromatase A, which is expressed mainly in the gonads, aromatase $B$, the product of the cyp19a1b gene, is mostly expressed in the brain, but also in the gonads [57]. Strikingly, it was found, first in toadfish [59] and then in rainbow trout and zebrafish [60,61], that the aromatase $B$ protein is only expressed in cells resembling radial glial cells. Such cells are present in the embryonic brain of all vertebrate species, but in mammals, they tend to disappear at birth to become star shaped astrocytes [62-64]. On the contrary, such cells remain abundant in the brain of adult fish, amphibians, birds and reptiles [60, 65-68].

The finding of aromatase expression in RGCs came as a surprise as no one had ever reported such an expression pattern in any other vertebrate. In contrast, in birds and mammals, it is admitted that aromatase expression is strictly confined to neurons under physiological conditions [29, 30]. When it was first reported that aromatase is expressed in RGC, virtually nothing was known on this particular cell type in the brain of any adult non-mammalian vertebrate. Since the pioneer studies performed in the late 70 s and early 80 s by the group of Gloria Callard it was known that the brain of fish exhibits a very high aromatase compared with other vertebrates $[69,70]$. Such a high aromatase was later reported in other species of fish, but the precise sites of expression were unknown [71-74]. It is only in 2001 that, intriguingly, aromatase mRNA and protein were reported in GFAP-positive cells and not in neurons of the toadfish $[59,75]$. This finding was later confirmed in several other species such as the rainbow trout, the zebrafish, the pejerrey, the Japanese eel, and the medaka [47, 60,61, 68, 76-78]. In all of these species, aromatase expression is restricted to RGCs which, according to the original definition of early neuroanatomists, are defined as cells exhibiting a small nucleus near the ventricular layer and long processes running radially through the parenchyma and terminating by endfeet at the periphery of the brain $[79,80]$. These cells were originally believed to serve as a scaffold for migration of new neurons born in the neuroepithelial region [81]. However, since then, a wealth of studies has documented the fact that these cells belong to the astroglial lineage and are actually pluripotent cells [63, 82, 83]. 
Again, the zebrafish is probably the best-documented species when it comes to aromatase expression and regulation in the brain of fish. In this species the evidence for aromatase expression in RGCs is based on $m R N A$ in situ hybridization, immunohistochemistry using two different kinds of antibodies to zebrafish aromatase B (Figure 2A) and GFP expression driven by cyp19a1b promoter [47, 48, 60, 68, 84]. All these techniques confirm each other and point to the RGCs as the unique cell type expressing aromatase in the zebrafish brain. Such cells are particularly abundant in all regions of the telencephalon, at all levels of the preoptic region, in the thalamus and the hypothalamus, in the optic tectum and the torus semicircularis. They are also found around the fourth ventricle and in the spinal cord all the way down to the tail. Very interestingly, in the zebrafish the cyp19a1b messengers are observed in the soma lining the ventricles, but also in the radial processes and in the endfeet lining the meninx, where they seem to accumulate [48]. Surprisingly, in the brain of the rainbow trout, messengers accumulate around the cell nuclei and did not appear to be massively exported in the radial processes [60]. The reason for these species differences are unknown at the moment. While no sexual dimorphism in aromatase expression was found in zebrafish, this is not the case in medaka where, in most regions, females have a greater degree of expression in the ventricular layer compared to males, with the optic tectum exhibiting the most conspicuous predominance in females [78]. It must be pointed out that studies in European sea bass did not evidence major sexual dimorphism in aromatase activity [74]. It is possible that sex dimorphism is more obvious in medaka, a species with a strong genetic sex determination, unlike zebrafish and sea bass.

\section{4 - Aromatase expression in the brain of zebrafish is strongly up-regulated by estrogen receptors}

In mammals, at least in rodents, aromatase expression and activity is highest during embryonic development and then decrease in adults [85, 86]. It is believed that this peak corresponds to the period of brain sexual differentiation which, at least in rodents, relies on aromatization of testosterone produced by the XY embryos [8]. In contrast, aromatase activity and expression in the brain of the zebrafish, and many other fish species, remain low during the embryonic period and start increasing during the period of sexual maturation corresponding to high levels of circulating sexual steroids such as estradiol and testosterone [74, 87-89]. In embryos, aromatase expression can be dramatically increased by exposing the animals to any 
estrogenic compound, including at very low doses $[60,84,90]$. In fact, the cyp19a1bgene is so sensitive to estrogens that it has been proposed as a biomarker for estrogenic exposure [90]. For example, the EC50 calculated from dose-response curves of GFP induction in transgenic cyp19a1b-GFP embryos are $0.48 \mathrm{nM}$ and $0.013 \mathrm{nM}$ for $17 \beta$-estradiol and $17 \alpha$-ethinylestradiol, respectively. This relationship between sex steroids levels and aromatase activity has been established long time ago, but it is only in 2005 that molecular dissections of the cyp19a1b promoter showed that an estrogen-responsive element (ERE) located upstream of the transcription start site is absolutely mandatory for up regulating of aromatase expression by estrogens [60]. The presence of functional ER is also mandatory as shown by in vitro and in vivo studies [60]. Surprisingly, aromatase expression is not observed at all in the numerous neurons expressing ER in any species of fish $[40,43$, $45,61]$, indicating that there is a strict cell specificity of expression of aromatase $B$ in the brain of fish and that, while ER expression is necessary, it is not sufficient. In fact, it was also shown that a sequence, named GxRE, located just upstream the ERE is equally mandatory for the response of the cyp19a1b gene to estradiol [91]. The hypothesis, which is supported by several lines of evidences is that the GxRE would bind a glial specific factor present in cells of the astrocyte lineage. Indeed, first experiments aiming at dissecting the molecular mechanisms of the estrogenic regulation of cyp19a1b in zebrafish showed that estradiol promotes expression of luciferase from a cyp19a1b-luciferase reporter construct, transfected together with any estrogen receptor, only in cells of the astrocyte lineage, such as U251-MG human astrocytes [60,91]. Additionally, it was shown that, as the GxRE harbours a perfect half binding-site for nuclear receptors (AGGTCA), it is likely that such transcription factors could cooperate with ERs in the context of the cyp19a1b gene. It was also evidenced by gel shift that the GxRE sequence binds nuclear extracts from cells of the astroglial lineage [91]. However, the identity of this factor still remains uncovered. The fact that the RGC phenotype is absolutely mandatory for aromatase expression is also demonstrated by the observation that, in the transgenic cyp19a1bGFP fish, GFP expression is rapidly lost in the new-born neuroblasts generated by RGC proliferation when they start migrating [90].

\section{5 - Aromatase-expressing radial glial cells proliferate and give birth to}

\section{neurons}


It has been know for some time that, in parallel to its dramatic aromatase expression, the brain of fish keeps growing in adult and exhibits an exceptional neurogenic activity in many brain regions [92-94]. Thus, the zebrafish is now a wellrecognized model for studying adult neurogenesis under constitutive and regenerative conditions [68, 95-102]. Using combinations of BrdU treatment, PCNA and aromatase as a marker of RGCs, it was shown that aromatase-positive radial cells actively divide to generate newborn cells in many forebrain regions [68]. Such newborn cells can further divide, as shown by BrdU-PCNA (Proliferating Cell Nuclear Antigen) double staining (Figure $2 \mathrm{~A}-\mathrm{C}$ ). It was also demonstrated that, over time, new-born cells move away from the ventricles, and migrate along the radial processes, before differentiating in neurons [68, 95, 98, 100].

Given that the estrogen-synthesizing enzyme aromatase $B$ is only expressed in RGCs, acting as neural precursors, this strongly suggests a role for estrogens in constitutive and reactive neurogenesis.

\section{2 - Effects of estrogens on neurogenesis in fish}

\section{1- Adult neurogenesis}

Recent studies addressed the question of the potential roles of estrogens on zebrafish adult neurogenesis by manipulating the levels of circulating estradiol. For example, treating animals with the aromatase inhibitor ATD caused total disappearance of gonadal and brain aromatase activities and a strong decrease in cyp19a1b gene expression, as expected. Evaluation of the number of PCNA positive cells in both males and females showed a consistent increase in brain cell proliferation that was significant in a limited number of regions [103]. However, inhibition of estrogen receptors using $\mathrm{ICl} 182,780$, which acts as a high affinity antagonist for nuclear receptor (IC50 $=0.29 \mathrm{nM})$ but presents GPR30 agonist properties, caused a significant increase in the number of PCNA positive cells in the olfactory bulb/telencephalon junction and the mediobasal hypothalamus [103]. These data, suggesting that estradiol inhibits rather than stimulates cell proliferation, were reinforced by the fact that, on the contrary, $17 \beta$-estradiol treatment induced a very significant decrease in PCNA positive cells in the telencephalon, mediobasal hypothalamus, periventricular pretectal nucleus and along the posterior recess of the hypothalamus [103]. Furthermore, fish exposure to $17 \beta$-estradiol also results in a decrease of newborn cell migration at the olfactory bulb/telencephalon junction and in the mediobasal hypothalamus. Cell survival was also affected by estradiol treatment 
resulting in a slight survival decrease at the junction between olfactory bulb and the telencephalon. Concerning cell differentiation, no differences were reported in this work [103]. Although these data need to be reinforced, they all suggest that estrogens inhibit cell proliferation and cell migration in adults.

Recently, cell proliferation pattern in the forebrain of adult zebrafish was reported to be sexually dimorphic [104]. Ampatzis and colleagues showed that proliferation is higher in females in the medial zone of the dorsal telencephalic area, the pretectal nucleus and the periventricular nucleus of the posterior tuberculum, whereas it is stronger in the dorsal zone of the periventricular hypothalamus in males [104]. Such data could reflect sex differences in the steroid and neurosteroids microenvironment and signalling beaten males and females.

\section{2-2 Reparative neurogenesis}

In mammals and birds, a wealth of data relates the role of estradiol in the cellular and molecular mechanisms underlying the neurogenic activity that takes place under physiological conditions [13, 105-107] but also in the context of brain repair. Following mechanical and chemical lesions induced in cerebral parenchyma, de novo expression of aromatase is described in reactive astrocytes around the injury site in mammals $[5,108]$ and in reactive astrocytes and radial glial cells in birds $[22,26,109]$ while under normal condition, the enzyme is mainly localized in neuronal cells. The induction of aromatase mRNA and protein at the injury site is associated with the onset of a high proliferative activity that is thought to contribute to the brain repair, suggesting a strong link between locally produced estradiol and reparative mechanisms. In contrast to the poor capability of the mammalian brain to regenerate after injury, the fish brain possesses a remarkable capacity to reconstruct entire brain regions [110]. Different studies in zebrafish have documented the fact that lesion of the telencephalon causes very high proliferative activity in the parenchyma and along the brain ventricles, corresponding mainly to the activation of microglia and oligodendrocytes [111, 112] and to a certain extent of radial glia [103]. However, aromatase B does not appear to be up-regulated in the proliferating cells [103]. An interesting observation is that, in contrast to birds and mammals, aromatase $B$ expression was rather inhibited in the vicinity of the damaged area. This is consistent with the observed inhibitory effect of estradiol on cell proliferation under physiological situations [103]. Furthermore, treating zebrafish with estradiol or ICI 182,720 does not appeared to affect cell proliferation after lesion [103]. However, E2 
impacts on newborn cells differentiation or migration have not been investigating and cannot therefore be excluded.

Taking advantage of the cyp19a1b-GFP transgenic fish line [84], our laboratory also showed that estradiol treatment on brain slices results in a rapid modulation of PGC and neuron activities [113]. Indeed, challenging these preparations with $17 \beta$-estradiol leads to a rapid increase of intracellular calcium levels in radial glia along the posterior recess of the hypothalamus and also in other cell-types probably corresponding to neurons according to their localization. Such effect of estrogens could possibly occur through the membrane-associated receptor G protein-coupled estrogen receptor 1 (GPER or GPR30), recently reported to be expressed in the adult zebrafish brain [114]. However, further investigations are necessary in order to confirm the presence of Gper in RGCs and to dissect the mechanisms of the rapid modulation on neural stem cell activity and neurons.

\section{2 -3 Embryonic neurogenesis}

We and other groups have shown, that the three estrogen receptors (esr1, esr2b and esr2a) are expressed during early development in zebrafish [115-117]. The messengers for the three receptors, in particular esr2a, are present in the eggs where they are maternally inherited. Transcripts levels drop down around 4-6 hpf (hour post-fecundation) and start increasing again when the embryonic genome is activated. All three receptor transcripts show a marked increase between $24 \mathrm{hpf}$ and $48 \mathrm{hpf}$ [117]. Furthermore, esr2a, esr2b and to a lower extent esr1, are detectable by in toto hybridization in different brain areas, mainly the hypothalamus and the preoptic area between 24 and 48 hpf [117]. In addition, cyp19a1b mRNA show parallel increase, notably between 24 and $48 \mathrm{hpf}$ indicating that aromatase B expression temporally correlates with that of esr [117]. Furthermore, using the cyp19a1b-GFP embryos, we could show that GFP expression in RGCs can be induced as early as $24 \mathrm{hpf}$, an effect that can be blocked by ICI182,780, indicating that esr are already functional at this time [117].

These results were confirmed recently by use of the morpholino (MO) approach showing that esr are fully functional at early developmental stages and exert regulatory actions on estrogen-target genes. Surprisingly, esr $2 b$ was the only MO that could block the induction of cyp19a1b [118]. The development of the lateral line was also studied using $\mathrm{MO}$ to block via esr2a showing that this receptor is 
essential for hair cell development, an effect that could involve interaction with the Notch signalling pathway [119].

Finally, recent studies also suggest a role of the G-protein-coupled estrogen receptor 1, Gper or GPR30 estrogens in brain development of zebrafish [120]. Gper seems to be strongly expressed in various regions of the developing brain and Gper knockdown by specific morpholinos leads to defects in brain development, causing decreased proliferation in the brain, increased apoptosis and defects in development of sensory and motor neurons [120].

\section{3 - Effects of estrogenic endocrine disrupting chemicals on brain development in fish}

Because of the above mentioned data showing that estrogens can influence neurogenesis in adults, the impact of estrogenic endocrine disruptors (EDs) on brain development requires attention. It is now clear that the developmental window is critically influenced by many exogenous factors and because these species are very precociously exposed, the structural and functional alterations induced by Eds may lead to significant changes and developmental failures. In light of the observations made in the natural environment, most studies covering the impact of EDs on fish reproduction have focused on the peripheral effects of these molecules. Thus, many data provide information about alterations of gonadal development, egg quality, sperm quality or vitellogenesis disruption [121]. Although the peripheral impacts of EDs are clearly established, their actions at the level of the brain are not sufficiently explored and need further considerations.

Based on the extreme sensitivity of the cyp19a1b gene to estrogens, we have used transgenic zebrafish to screen the potential impact of a large spectrum of natural and synthetic molecules (including estrogens, progestagens, androgens) or industrial chemicals (bisphenol A, pesticides). Approximately half of the 45 compounds investigated in that study stimulate in a dose-dependant manner the cyp19a1b-driven GFP expression in radial glia in 5 days larvae. This indicates that many chemicals present in the water can readily access the brain and modify gene expression in brain stem cells. The cyp19a1b gene is not the only gene to be

modulated by estradiol or estrogenic EDs. Estradiol, bisphenol $A$ and diéthylstilbestrol also up-regulate expression of ER [116, 122] and nuclear progesterone receptors in zebrafish embryos [123]. One can expect that a large set 
of genes is affected by early exposure to estrogens and xenoestrogens with a wide spectrum of consequences in term of brain development and functioning.

Among the potential EDs affecting brain ontogeny, 17a-ethinylestradiol (EE2) is a potent estrogenic molecule widely used in contraceptive pills production and therefore found in waters released from water treatment units. It has been shown that low doses of EE2 disrupts the development of GnRH neuronal network in zebrafish embryos and larvae by increasing the number of $\mathrm{GnRH}$-immunoreactive neurons and fibers in the forebrain and by modifying the migration pattern of $\mathrm{GnRH}$ neurons [124, 125]. However, the underlying mechanisms are unknown. Recent data in our laboratory indicate that exposure to low concentrations of EE2 $\left(10^{-10}\right.$ and $\left.10^{-11} \mathrm{M}\right)$ causes abnormal development, increase esr and npr transcript levels and reduces expression of pcna in the brain (A. Nasri et al., unpublished).

While 4-nonylphenol (4-NP) is not estrogenic, nonyphenol mixtures released in water from manufacturing industries and wastewater treatment units possess weak estrogenic activity [90]. The potential effects of NP mixtures on brain development have not been studies so far, however similar to EE2, NP mixtures affect the development of the GnRH systems in developing zebrafish [115[90].

Bisphenol A (BPA), a plastic monomer, has been identified as a xeno-estrogen that can interfere with endogenous estrogen signalling. Since 1950, BPA is a component of a large variety of consumer products, including food containers. Whole mount in situ hybridization has revealed that BPA (5 to $10 \mu \mathrm{M}$ ) induces a strong expression of aromatase $B$ in the brain of developing zebrafish, an induction that is largely dependant of ER nuclear receptors [126]. In the EASZY screening assay that makes use of cyp19a1b-GFP transgenic zebrafish, the EC50 of BPA is $3 \mu \mathrm{M}$, confirming that BPA behaves as a weak estrogen. At this concentration, found in some locations near BPA manufacturing sites [127], BPA exposure for 5 days induces expression of GFP in radial glial cells indicating that some disruption occurs with unknown consequences [126]. Whole mount in situ hybridization has revealed that BPA exposure (10 to $75 \mu \mathrm{M}$ ) impairs the normal development during early embryogenesis leading to cell fate determination disruption and organogenesis defects [126]. In BPA-exposed zebrafish, there is a clear disturbance of the early brain regionalization processes as revealed by inappropriate and unorganized expression of neuronal organization markers as pax2a, otx2, krox2 and eng $2 \mathrm{~b}$. As a result of these abnormal expressions of regionalization markers during 24 hours of 
BPA-exposure, rhombomeres are completely unstructured, the mid-hindbrain boundary minimized in size as the midbrain structure [126]. It must however be pointed out that the dose of BPA $(50 \mu \mathrm{M})$ employed in this study is rather high. Still in zebrafish embryos, BPA treatment $(1-15 \mu \mathrm{M})$ also had adverse impact on motor behavior. The locomotion changes induced by BPA results from an abnormal axonal growth of spinal motoneurons leading to a strong deficit of spontaneaous and stimulated swimming activity of embryos and larvae [128, 129]. The use of transcriptomic analysis of BPA-exposed zebrafish larvae of 5 days reveals that several muscular and neuronal markers (including synaptic long-term potentiation or axonal guidance molecules) may be de-regulated by the xeno-estrogen larva [128, 129]. BPA exposure (from $10^{-8} \mathrm{M}$ to $10^{-4} \mathrm{M}$ ) was also shown to cause dose-dependent malformations of the otic vesicle in zebrafish and in Xenopus embryos. However, this effect seems to be independent of estrogen receptors or thyroid-hormone receptors [130]. BPA (from 0,01 to $1 \mu \mathrm{M}$ ) probably permanently affects brain and behavior development during early life-stages because transient exposure of zebrafish embryos from $8 \mathrm{hpf}$ to $120 \mathrm{hpf}$ elicits in adults long term learning deficits as evidenced by T-maze testing protocol [131]. Recently, it has been shown that early exposures to halogenated-BPA analogs have permanent effects on lipid metabolism in the larvae but also in juveniles. The accumulation of lipids observed in zebrafish treated with halogenated-BPAs correlates with PPAR $\gamma$ (peroxysome proliferatoractivated receptor gamma), a key nuclear factor in the regulation of adipogenesis. These results strongly suggest that BPA and its analogs may constitute obesogenic compounds whose role in the onset of obesity is increasingly suspected [132].

\section{4 - Estrogen receptors and aromatase in the brain of amphibians}

Until recently, there was no accurate information on the sites of aromatase expression in amphibians, which share common ancestors with the large synapsid group including all mammals. Therefore, it is relevant here to review the available information regarding the situation in amphibians.

\section{4 .1- Estrogen receptors in the brain of amphibians}

Two (ERa, ERß) or three (ER $\alpha 1, E R \alpha 2, E R \beta)$ isoforms of estrogen receptor has been identified in Xenopus Laevis or Xenopus tropicalis, respectively [133-136]. Analyses of the estrogen receptors expression in the central nervous system were 
restricted to specific developmental stages (NF51; 60 and 66) and based on Q-PCR studies [137, 138]. In Xenopus tropicalis, ERa and ERß genes are expressed at low level in the brain at larval stage 51 (before gonadal sex differentiation which occur between NF54 and NF59 stages), but become extremely abundant in the larva at stage 60 (metamorphic climax). They remain expressed at relatively high levels after metamorphosis, i.e at juvenile stages $[137,139]$. The precise distribution of estrogen receptors mRNA or proteins have not been studied during development in amphibian species. To the best of our knowledge, estrogen receptors have only been localized in adult animals, using in situ hybridization, in the brain of the tungara frogs (Physalaemus pustulosus) and, using immunohistochemistry methods, in the male roughskin newt (Taricha granulosa) [140-142].. In Physalaemus pustulosus, ERa and ERß expressions were found mostly in limbic areas (e.g. preoptic areas, hypothalamus, nucleus accumbens, striatum, septum, amygdala), parts of thalamus, in the laminar nucleus of the torus semicircularis and the pallium (medial and dorsal). Males and females had similar anatomical distributions of ER $\alpha$ and ERß expression in the brain. Importantly, no sex differences in the expression levels of ERs were found in the preoptic area, hypothalamus and septal region. However, females had higher ERß and ERa expression than males in the laminar and principal nuclei of the torus semicircularis [140]. ERß expression was many-fold higher than ERa in the preoptic area suggesting that ERß plays an important role in modulating sexual behavior in anurans.

\section{2- Cyp19a1 gene expression and regulation in the brain of amphibians}

In amphibians also, there is now clear evidence that the brain is a steroidogenic organ, and that neurosteroids might play important developmental or physiological roles in the brain [143-145]. Studies based on in vitro biochemical analyses performed with brain extracts identified estrogen synthesizing enzyme activity, and therefore possible neuroestrogen synthesis in various adult brain areas of some amphibian species. Briefly, aromatase activity has been detected in the preoptic area, hypothalamus and amygdala of Rana catesbeiana (Necturius maculosus) [69]. A high level of aromatase activity was also detected in the hypothalamus of female Rana catesbeiana [142].

The cytochrome P450 aromatase, is encoded by a single cyp19a1 gene in amphibians. In Xenopus laevis and Pleurodeles waltl, cyp19a1 gene expression leads to two gonadal and one brain transcripts differing in their 5-untranslated region 
(UTR), but containing an identical open reading frame [146, 147]. During development, brain expression of cyp19a1 was investigated by RT-PCR experiments in Xenopus [146, 148-150] and Pleurodeles waltl [151]. In both species, the cyp19a1 gene is expressed in the brain from early developmental stages to metamorphosis and no sex differences in aromatase activity was detected at any larval stages [151].

Recent results in Xenopus laevis provided the first detailed information on the distribution of cyp19a1 mRNAs in amphibian during pre- and in post-metamorphic development. It was found that cyp19a1 expression in the brain is initiated from early larval stage (stage NF42) and remains elevated until post-metamorphic stages [152]. The highest expression was detected during developmental stages in the preoptic area and in the caudal hypothalamus; two regions known for their implication in calling and sexual behavior. Minor sites of cyp19a1 expression were also detected in the septum, bed nucleus of the stria terminalis, amygdala and ventral thalamus. Importantly, using various cellular markers, it was fond that cyp19a1 transcripts are strictly expressed in neuronal cells, and not in radial glial or progenitor cells located in the ventricular layers of developing Xenopus laevis brain. Recent data also provide evidence that adult males and females exhibit similar expression levels and distribution patterns ( $P$. Coumailleau et al., unpublished). Several attempts were made to localize the aromatase protein, notably in Rana esculenta (Pelophylax esculentus) using commercial antibodies [153]. These data, based on uncharacterized heterologous antibodies, do not fully match aboved in situ hybridization data based on the use of specific X.laevis riboprobe. It thus appears that similar to mammals, immunohistochemistry of aromatase is difficult to achieve in amphibians.

The molecular mechanism underlying the brain-specific cyp19a1 gene expression in Xenopus laevis is depending on a recently identified brain specific promoter, promoter I.f, exhibiting potential cis-elements for several transcriptional factors, such as Oct-1, c-Myc, the GATA gene family, but no estrogen-responsive element [154]. Virtually nothing is known on the potential effects of steroids on brain sexual differentiation. It is admitted that gonadal aromatase plays a key role in the sex differentiation of Xenopus gonads [155-157]. In this later species, aromatase activity level fluctuated throughout the reproductive cycle in females with the highest levels during the breeding and recovery periods [142]. Sex steroids are involved in gonadal differentiation in frogs [158] and amphibians, including Xenopus laevis, are 
relatively sensitive to steroid hormones when exposed during the critical period of sexual determination and differentiation of the gonads [155, 157]. Interestingly, in Xenopus laevis, cyp19a1 is expressed at 5-fold higher level in the brain than in the gonads at the time of sex differentiation $[146,150]$.

\section{3- Endocrine disrupting compounds (EDC) in amphibians}

Aromatase is considered as one of the potential targets of the many environmental chemicals (EDC) that can interfere with the endocrine system affecting the reproductive biology of aquatic vertebrates [159-161]. In Xenopus, EDCs can interfere with the hypothalamic-pituitary-gonad (HPG) axis and affect various aspects of reproduction via (anti)estrogenic and (anti)androgenic modes of action [162-164]. In addition, a significant correlation exist between exposure to potent xenoestrogens and delay of metamorphosis in various amphibian species [161, 165]. The mechanism by which estrogenic substances inhibit larval development might be due to a crosstalk between estrogen receptor and thyroid hormone receptor $[161,166]$.

\section{5 - Evolutive consideration and conclusions}

The data obtained recently in Xenopus [152] clearly highlight the apparently unique features of the teleost brain regarding aromatase expression and regulation in radial glial cells. There is a single report in the mammalian literature suggesting that aromatase and ER are expressed in RGCs of the developing cortex of mouse where estrogens would stimulate cell proliferation [167]. However, despite our efforts, we could not confirm theses observations. Thus, teleost fish remain the only vertebrates in which aromatase is so strongly and exclusively expressed in RGCs.

Unfortunately, very little is known in basal groups of vertebrates, which makes it difficult to know what exactly was the ancestral situation in basal vertebrates and how this situation might have evolved over time. Clearly, the role of aromatase and estrogen receptors in the brain of lampreys and sharks would bring valuable information from an evolutive point of view. To our knowledge, there is no report regarding aromatase in lamprey, but it is know that the dogfish exhibits significant aromatase and 5a-reductase activity in the brain [69]. In the stingray, a chondrostean fish, a single gene has been cloned with expression in both the brain and the gonad. In the brain, transcripts were found in all major brain divisions, however the precise sites of expression are unknown [168]. 
Recently, information was released on the Japanese eel, a basal teleost species, belonging to the Elopomorph order in which there is a single cyp19a1 gene, which is expressed in both the gonads and the brain [169]. Specific antibodies could be produced against the aromatase protein produced by this single gene and it was found, very interestingly, that both cyp19a1 transcripts and protein were unambiguously present in RGCs of both males and females [76]. It was also shown that aromatase expression in the brain is up-regulated by sex steroids notably estrogens [170, 171 ]. Thus, this single gene most likely has a brain promoter driving expression and regulation of aromatase in a way similar to what is found in other teleosts with two cyp19a1 genes. As it is known that eels have 8 hox complexes [172] and thus underwent the teleost specific whole genome duplication, it is suggested that from an ancestral gene having brain and gonad functions similar to those found in other teleosts, the $3 \mathrm{R}$ whole genome duplication gave birth to two copies that evolved differently in Elopomorphs (Eels) and other teleosts. Soon after the duplication, eels probably lost one copy of the cyp19a1 gene and the remaining copy retained brain and gonad functions. In other teleost fishes, a subfunctionalization process probably occurred that led to partition of functions between the two copies, cyp19a1a (gonad) and cyp19a1b (brain) [76]. This could mean that the ancestor of the cyp19a1 gene in basal actinopterygian fishes already had such characteristics. However, unfortunately, in the actinopterygian lineage, information is limited to teleosts and data are not available in chondrostei nor in holostei.

The only really clear function that has emerged since researchers started to delve into the potential roles of aromatase expression in the brain is its implication on the masculinization and defeminization of the developing rodent brain, causing irreversible sexualization [8]. Clearly, this cannot apply to teleost fishes, in which one can find a very large sample of sexual strategies, ranging from strict gonochorism to simultaneous hermaphrodism. Some fish species can rapidly change sex depending on social cues or determine their sex according to the availability of partners [33]. Steroid or neurosteroid-dependent expression of aromatase in progenitors and effects of estrogens on neurogenesis certainly open the door to unique possibilities in terms of brain plasticity. However, until conditional knock-out of cyp19a1a and cyp19a1b are performed, it will be very difficult to fully understand what makes the fish so special compared to other vertebrates. 
Another interesting point of discussion concerns the fact that several studies mentioned aromatase expression in astrocytes of birds and mammals following chemical or mechanical lesions [23, 25, 26]. In addition, there are reports indicating that reactive astrocytes can be neurogenic [173-176] and that astrocytes retain the property of generating neurons under some physiological situations [177]. Teleost fishes, at least in the forebrain, do not possess bona fide astrocytes and it is likely that RGCs in fish share some common features with reactive astrocytes. Because reactive astrocytes are critical for the process of brain repair, we cannot exclude that the outstanding capacity of the teleost brain to regenerate after lesions is linked to these common characteristics. 


\section{References}

[1] E.A. Doisy, S.A. Thayer, The Oestrus-Producing Hormones, Science 75 (1932) 216-217.

[2] B. Zondek, Estrogenic Hormone in the Urine of the Stallion, Nature 133 (1934) 494-494.

[3] S.E. Bulun, K. Takayama, T. Suzuki, H. Sasano, B. Yilmaz, S. Sebastian, Organization of the human aromatase p450 (CYP19) gene, Seminars in reproductive medicine 22 (2004) 5-9.

[4] I. Azcoitia, J.G. Yague, L.M. Garcia-Segura, Estradiol synthesis within the human brain, Neuroscience 191 (2011) 139-147.

[5] L.M. Garcia-Segura, Aromatase in the brain: not just for reproduction anymore, Journal of neuroendocrinology 20 (2008) 705-712.

[6] E.D. Lephart, A review of brain aromatase cytochrome P450, Brain research. Brain research reviews 22 (1996) 1-26.

[7] A. Jost, Hormonal factors in the sex differentiation of the mammalian foetus, Philosophical transactions of the Royal Society of London. Series B, Biological sciences 259 (1970) 119-130.

[8] N.J. MacLusky, A. Philip, C. Hurlburt, F. Naftolin, Estrogen formation in the developing rat brain: sex differences in aromatase activity during early post-natal life, Psychoneuroendocrinology 10 (1985) 355-361.

[9] R.B. Simerly, Wired on hormones: endocrine regulation of hypothalamic development, Current opinion in neurobiology 15 (2005) 81-85.

[10] E.M. Waters, R.B. Simerly, Estrogen induces caspase-dependent cell death during hypothalamic development, The Journal of neuroscience : the official journal of the Society for Neuroscience 29 (2009) 9714-9718.

[11] G.E. Gillies, S. McArthur, Estrogen actions in the brain and the basis for differential action in men and women: a case for sex-specific medicines, Pharmacological reviews 62 (2010) 155-198.

[12] J. Bayer, G. Rune, K. Kutsche, U. Schwarze, R. Kalisch, C. Buchel, T. Sommer, Estrogen and the male hippocampus: genetic variation in the aromatase gene predicting serum estrogen is associated with hippocampal gray matter volume in men, Hippocampus 23 (2013) 117-121.

[13] J.M. Bowers, J. Waddell, M.M. McCarthy, A developmental sex difference in hippocampal neurogenesis is mediated by endogenous oestradiol, Biology of sex differences 1 (2010) 8.

[14] T.M. Bredemann, L.L. McMahon, 17beta Estradiol increases resilience and improves hippocampal synaptic function in helpless ovariectomized rats, Psychoneuroendocrinology 42 (2014) 77-88.

[15] S. Suzuki, C.M. Brown, P.M. Wise, Neuroprotective effects of estrogens following ischemic stroke, Frontiers in neuroendocrinology 30 (2009) 201-211.

[16] J. Waddell, J.M. Bowers, N.S. Edwards, C.L. Jordan, M.M. McCarthy, Dysregulation of neonatal hippocampal cell genesis in the androgen insensitive Tfm rat, Hormones and behavior 64 (2013) 144-152.

[17] I. Czajka-Oraniec, E.R. Simpson, Aromatase research and its clinical significance, Endokrynologia Polska 61 (2010) 126-134.

[18] A.F. De Nicola, M.E. Brocca, L. Pietranera, L.M. Garcia-Segura, Neuroprotection and sex steroid hormones: evidence of estradiol-mediated protection in hypertensive encephalopathy, Mini reviews in medicinal chemistry 12 (2012) 1081-1089. 
[19] B. Filova, D. Ostatnikova, P. Celec, J. Hodosy, The effect of testosterone on the formation of brain structures, Cells, tissues, organs 197 (2013) 169-177.

[20] L. Remage-Healey, C.J. Saldanha, B.A. Schlinger, Estradiol synthesis and action at the synapse: evidence for "synaptocrine" signaling, Frontiers in endocrinology 2 (2011) 28.

[21] C.J. Saldanha, S.R. Burstein, K.A. Duncan, Induced synthesis of oestrogens by glia in the songbird brain, Journal of neuroendocrinology 25 (2013) 1032-1038.

[22] C.J. Saldanha, K.A. Duncan, B.J. Walters, Neuroprotective actions of brain aromatase, Frontiers in neuroendocrinology 30 (2009) 106-118.

[23] L.M. Garcia-Segura, A. Wozniak, I. Azcoitia, J.R. Rodriguez, R.E. Hutchison, J.B. Hutchison, Aromatase expression by astrocytes after brain injury: implications for local estrogen formation in brain repair, Neuroscience 89 (1999) 567-578.

[24] S. Luchetti, C.G. van Eden, K. Schuurman, M.E. van Strien, D.F. Swaab, I. Huitinga, Gender differences in multiple sclerosis: induction of estrogen signaling in male and progesterone signaling in female lesions, Journal of neuropathology and experimental neurology 73 (2014) 123-135.

[25] R.S. Peterson, G. Fernando, L. Day, T.A. Allen, J.D. Chapleau, J. Menjivar, B.A. Schlinger, D.W. Lee, Aromatase expression and cell proliferation following injury of the adult zebra finch hippocampus, Developmental neurobiology 67 (2007) 1867-1878.

[26] R.S. Peterson, D.W. Lee, G. Fernando, B.A. Schlinger, Radial glia express aromatase in the injured zebra finch brain, The Journal of comparative neurology 475 (2004) 261-269.

[27] R.S. Peterson, C.J. Saldanha, B.A. Schlinger, Rapid upregulation of aromatase mRNA and protein following neural injury in the zebra finch (Taeniopygia guttata), Journal of neuroendocrinology 13 (2001) 317-323.

[28] R.D. Spence, Y. Zhen, S. White, B.A. Schlinger, L.B. Day, Recovery of motor and cognitive function after cerebellar lesions in a songbird: role of estrogens, The European journal of neuroscience 29 (2009) 1225-1234.

[29] J. Balthazart, P. Absil, A. Foidart, M. Houbart, N. Harada, G.F. Ball, Distribution of aromatase-immunoreactive cells in the forebrain of zebra finches (Taeniopygia guttata): implications for the neural action of steroids and nuclear definition in the avian hypothalamus, Journal of neurobiology 31 (1996) 129-148.

[30] J. Balthazart, G.F. Ball, New insights into the regulation and function of brain estrogen synthase (aromatase), Trends in neurosciences 21 (1998) 243-249.

[31] C.M. Campbell, A. Fostier, B. Jalabert, B. Truscott, Identification and quantification of steroids in the serum of rainbow trout during spermiation and oocyte maturation, The Journal of endocrinology 85 (1980) 371-378.

[32] A.P. Scott, J.P. Sumpter, P.A. Hardiman, Hormone changes during ovulation in the rainbow trout (Salmo gairdneri Richardson), General and comparative endocrinology 49 (1983) 128-134.

[33] J. Godwin, Neuroendocrinology of sexual plasticity in teleost fishes, Frontiers in neuroendocrinology 31 (2010) 203-216.

[34] D. Steinke, S. Hoegg, H. Brinkmann, A. Meyer, Three rounds (1R/2R/3R) of genome duplications and the evolution of the glycolytic pathway in vertebrates, BMC biology 4 (2006) 16.

[35] F. Pakdel, S. Feon, F. Le Gac, F. Le Menn, Y. Valotaire, In vivo estrogen induction of hepatic estrogen receptor mRNA and correlation with vitellogenin mRNA in rainbow trout, Molecular and cellular endocrinology 75 (1991) 205-212. 
[36] F. Pakdel, F. Le Gac, P. Le Goff, Y. Valotaire, Full-length sequence and in vitro expression of rainbow trout estrogen receptor cDNA, Molecular and cellular endocrinology 71 (1990) 195-204.

[37] S. Green, P. Walter, V. Kumar, A. Krust, J.M. Bornert, P. Argos, P. Chambon, Human oestrogen receptor cDNA: sequence, expression and homology to v-erb-A, Nature 320 (1986) 134-139.

[38] R. Metivier, F.G. Petit, Y. Valotaire, F. Pakdel, Function of N-terminal transactivation domain of the estrogen receptor requires a potential alpha-helical structure and is negatively regulated by the A domain, Molecular endocrinology 14 (2000) 1849-1871.

[39] F. Pakdel, R. Metivier, G. Flouriot, Y. Valotaire, Two estrogen receptor (ER) isoforms with different estrogen dependencies are generated from the trout ER gene, Endocrinology 141 (2000) 571-580.

[40] A. Menuet, I. Anglade, G. Flouriot, F. Pakdel, O. Kah, Tissue-specific expression of two structurally different estrogen receptor alpha isoforms along the female reproductive axis of an oviparous species, the rainbow trout, Biology of reproduction 65 (2001) 1548-1557.

[41] G.G. Kuiper, E. Enmark, M. Pelto-Huikko, S. Nilsson, J.A. Gustafsson, Cloning of a novel receptor expressed in rat prostate and ovary, Proceedings of the National Academy of Sciences of the United States of America 93 (1996) 5925-5930.

[42] M.B. Hawkins, J.W. Thornton, D. Crews, J.K. Skipper, A. Dotte, P. Thomas, Identification of a third distinct estrogen receptor and reclassification of estrogen receptors in teleosts, Proceedings of the National Academy of Sciences of the United States of America 97 (2000) 10751-10756.

[43] A. Menuet, E. Pellegrini, I. Anglade, O. Blaise, V. Laudet, O. Kah, F. Pakdel, Molecular characterization of three estrogen receptor forms in zebrafish: binding characteristics, transactivation properties, and tissue distributions, Biology of reproduction 66 (2002) 1881-1892.

[44] G. Salbert, G. Bonnec, P. Le Goff, D. Boujard, Y. Valotaire, P. Jego, Localization of the estradiol receptor mRNA in the forebrain of the rainbow trout, Molecular and cellular endocrinology 76 (1991) 173-180.

[45] I. Anglade, F. Pakdel, T. Bailhache, F. Petit, G. Salbert, P. Jego, Y. Valotaire, O. Kah, Distribution of estrogen receptor-immunoreactive cells in the brain of the rainbow trout (Oncorhynchus mykiss), Journal of neuroendocrinology 6 (1994) 573-583.

[46] F. Pakdel, F. Petit, I. Anglade, O. Kah, F. Delaunay, T. Bailhache, Y. Valotaire, Overexpression of rainbow trout estrogen receptor domains in Escherichia coli: characterization and utilization in the production of antibodies for immunoblotting and immunocytochemistry, Molecular and cellular endocrinology 104 (1994) 81-93.

[47] N. Diotel, Y. Le Page, K. Mouriec, S.K. Tong, E. Pellegrini, C. Vaillant, I. Anglade, F. Brion, F. Pakdel, B.C. Chung, O. Kah, Aromatase in the brain of teleost fish: expression, regulation and putative functions, Frontiers in neuroendocrinology 31 (2010) 172-192.

[48] E. Pellegrini, A. Menuet, C. Lethimonier, F. Adrio, M.M. Gueguen, C. Tascon, I. Anglade, F. Pakdel, O. Kah, Relationships between aromatase and estrogen receptors in the brain of teleost fish, General and comparative endocrinology 142 (2005) 60-66. 
[49] B. Muriach, M. Carrillo, S. Zanuy, J.M. Cerda-Reverter, Distribution of estrogen receptor 2 mRNAs (Esr2a and Esr2b) in the brain and pituitary of the sea bass (Dicentrarchus labrax), Brain research 1210 (2008) 126-141.

[50] B. Muriach, J.M. Cerda-Reverter, A. Gomez, S. Zanuy, M. Carrillo, Molecular characterization and central distribution of the estradiol receptor alpha (ERalpha) in the sea bass (Dicentrarchus labrax), Journal of chemical neuroanatomy 35 (2008) 33-48.

[51] S. Kanda, Y. Akazome, Y. Mitani, K. Okubo, Y. Oka, Neuroanatomical evidence that kisspeptin directly regulates isotocin and vasotocin neurons, PloS one 8 (2013) e62776.

[52] B. Zempo, S. Kanda, K. Okubo, Y. Akazome, Y. Oka, Anatomical distribution of sex steroid hormone receptors in the brain of female medaka, The Journal of comparative neurology 521 (2013) 1760-1780.

[53] B. Linard, I. Anglade, M. Corio, J.M. Navas, F. Pakdel, C. Saligaut, O. Kah, Estrogen receptors are expressed in a subset of tyrosine hydroxylase-positive neurons of the anterior preoptic region in the rainbow trout, Neuroendocrinology 63 (1996) 156-165.

[54] I. Anglade, D. Mazurais, V. Douard, C. Le Jossic-Corcos, E.L. Mananos, D. Michel, O. Kah, Distribution of glutamic acid decarboxylase mRNA in the forebrain of the rainbow trout as studied by in situ hybridization, The Journal of comparative neurology 410 (1999) 277-289.

[55] Y. Mitani, S. Kanda, Y. Akazome, B. Zempo, Y. Oka, Hypothalamic Kiss1 but not Kiss2 neurons are involved in estrogen feedback in medaka (Oryzias latipes), Endocrinology 151 (2010) 1751-1759.

[56] S. Escobar, A. Felip, M.M. Gueguen, S. Zanuy, M. Carrillo, O. Kah, A. Servili, Expression of kisspeptins in the brain and pituitary of the European sea bass (Dicentrarchus labrax), The Journal of comparative neurology 521 (2013) 933948.

[57] A. Tchoudakova, G.V. Callard, Identification of multiple CYP19 genes encoding different cytochrome $\mathrm{P} 450$ aromatase isozymes in brain and ovary, Endocrinology 139 (1998) 2179-2189.

[58] S. van Nes, M. Moe, O. Andersen, Molecular characterization and expression of two cyp19 (P450 aromatase) genes in embryos, larvae, and adults of Atlantic halibut (Hippoglossus hippoglossus), Molecular reproduction and development 72 (2005) 437-449.

[59] P.M. Forlano, D.L. Deitcher, D.A. Myers, A.H. Bass, Anatomical distribution and cellular basis for high levels of aromatase activity in the brain of teleost fish: aromatase enzyme and mRNA expression identify glia as source, The Journal of neuroscience : the official journal of the Society for Neuroscience 21 (2001) 8943-8955.

[60] A. Menuet, E. Pellegrini, F. Brion, M.M. Gueguen, I. Anglade, F. Pakdel, O. Kah, Expression and estrogen-dependent regulation of the zebrafish brain aromatase gene, The Journal of comparative neurology 485 (2005) 304-320.

[61] A. Menuet, I. Anglade, R. Le Guevel, E. Pellegrini, F. Pakdel, O. Kah, Distribution of aromatase mRNA and protein in the brain and pituitary of female rainbow trout: Comparison with estrogen receptor alpha, The Journal of comparative neurology 462 (2003) 180-193.

[62] P. Malatesta, M. Gotz, Radial glia - from boring cables to stem cell stars, Development 140 (2013) 483-486. 
[63] L. Pinto, M. Gotz, Radial glial cell heterogeneity--the source of diverse progeny in the CNS, Progress in neurobiology 83 (2007) 2-23.

[64] A. Kriegstein, A. Alvarez-Buylla, The glial nature of embryonic and adult neural stem cells, Annual review of neuroscience 32 (2009) 149-184.

[65] L.A. D'Amico, D. Boujard, P. Coumailleau, Proliferation, migration and differentiation in juvenile and adult Xenopus laevis brains, Brain Res 1405 (2011) 31-48.

[66] L.A. D'Amico, D. Boujard, P. Coumailleau, The neurogenic factor NeuroD1 is expressed in post-mitotic cells during juvenile and adult Xenopus neurogenesis and not in progenitor or radial glial cells, PLoS One 8 (2013) e66487.

[67] B. Onteniente, H. Kimura, T. Maeda, Comparative study of the glial fibrillary acidic protein in vertebrates by PAP immunohistochemistry, J Comp Neurol 215 (1983) 427-436.

[68] E. Pellegrini, K. Mouriec, I. Anglade, A. Menuet, Y. Le Page, M.M. Gueguen, M.H. Marmignon, F. Brion, F. Pakdel, O. Kah, Identification of aromatase-positive radial glial cells as progenitor cells in the ventricular layer of the forebrain in zebrafish, The Journal of comparative neurology 501 (2007) 150-167.

[69] G.V. Callard, Z. Petro, K.J. Ryan, Phylogenetic distribution of aromatase and other androgen-converting enzymes in the central nervous system, Endocrinology 103 (1978) 2283-2290.

[70] M. Pasmanik, B.A. Schlinger, G.V. Callard, In vivo steroid regulation of aromatase and 5 alpha-reductase in goldfish brain and pituitary, General and comparative endocrinology 71 (1988) 175-182.

[71] B. Borg, R.J. Timmers, J.G. Lambert, Aromatase activity in the brain of the threespined stickleback, Gasterosteus aculeatus. I. Distribution and effects of season and photoperiod, Experimental biology 47 (1987) 63-68.

[72] R.J. Timmers, J.G. Lambert, J. Peute, H.G. Vullings, P.G. van Oordt, Localization of aromatase in the brain of the male African catfish, Clarias gariepinus (Burchell), by microdissection and biochemical identification, The Journal of comparative neurology 258 (1987) 368-377.

[73] B. Borg, E. Andersson, I. Mayer, J.G. Lambert, Aromatase activity in the brain of the three-spined stickleback, Gasterosteus aculeatus. III. Effects of castration under different conditions and of replacement with different androgens, Experimental biology 48 (1989) 149-152.

[74] A. Gonzalez, F. Piferrer, Aromatase activity in the European sea bass (Dicentrarchus labrax L.) brain. Distribution and changes in relation to age, sex, and the annual reproductive cycle, General and comparative endocrinology 132 (2003) 223-230.

[75] P.M. Forlano, A.H. Bass, Seasonal plasticity of brain aromatase mRNA expression in glia: divergence across sex and vocal phenotypes, Journal of neurobiology 65 (2005) 37-49.

[76] S.R. Jeng, W.S. Yueh, Y.T. Pen, M.M. Gueguen, J. Pasquier, S. Dufour, C.F. Chang, O. Kah, Expression of aromatase in radial glial cells in the brain of the Japanese eel provides insight into the evolution of the cyp191a gene in Actinopterygians, PloS one 7 (2012) e44750.

[77] P.H. Strobl-Mazzulla, A. Nunez, E. Pellegrini, M.M. Gueguen, O. Kah, G.M. Somoza, Progenitor radial cells and neurogenesis in pejerrey fish forebrain, Brain, behavior and evolution 76 (2010) 20-31. 
[78] K. Okubo, A. Takeuchi, R. Chaube, B. Paul-Prasanth, S. Kanda, Y. Oka, Y. Nagahama, Sex differences in aromatase gene expression in the medaka brain, Journal of neuroendocrinology 23 (2011) 412-423.

[79] M. Bentivoglio, P. Mazzarello, The history of radial glia, Brain research bulletin 49 (1999) 305-315.

[80] V. Garcia-Marin, P. Garcia-Lopez, M. Freire, Cajal's contributions to glia research, Trends in neurosciences 30 (2007) 479-487.

[81] P. Rakic, Neuronal migration and contact guidance in the primate telencephalon, Postgraduate medical journal 54 Suppl 1 (1978) 25-40.

[82] L. Xu, X. Tang, Y. Wang, H. Xu, X. Fan, Radial Glia, the Keystone of the Development of the Hippocampal Dentate Gyrus, Molecular neurobiology (2014).

[83] J. Morrens, W. Van Den Broeck, G. Kempermann, Glial cells in adult neurogenesis, Glia 60 (2012) 159-174.

[84] S.K. Tong, K. Mouriec, M.W. Kuo, E. Pellegrini, M.M. Gueguen, F. Brion, O. Kah, B.C. Chung, A cyp19a1b-gfp (aromatase B) transgenic zebrafish line that expresses GFP in radial glial cells, Genesis 47 (2009) 67-73.

[85] F.W. George, S.R. Ojeda, Changes in aromatase activity in the rat brain during embryonic, neonatal, and infantile development, Endocrinology 111 (1982) 522529.

[86] E.D. Lephart, E.R. Simpson, M.J. McPhaul, M.W. Kilgore, J.D. Wilson, S.R. Ojeda, Brain aromatase cytochrome P-450 messenger RNA levels and enzyme activity during prenatal and perinatal development in the rat, Brain research. Molecular brain research 16 (1992) 187-192.

[87] B. Borg, R.J. Timmers, J.G. Lambert, Aromatase activity in the brain of the threespined stickleback, Gasterosteus aculeatus. II. Effects of castration in winter, Experimental biology 47 (1987) 69-71.

[88] M. Pasmanik, G.V. Callard, Changes in brain aromatase and 5 alpha-reductase activities correlate significantly with seasonal reproductive cycles in goldfish (Carassius auratus), Endocrinology 122 (1988) 1349-1356.

[89] I. Mayer, B. Borg, I. Berglund, J.G. Lambert, Effects of castration and androgen treatment on aromatase activity in the brain of mature male Atlantic salmon (Salmo salar L.) parr, General and comparative endocrinology 82 (1991) 86-92.

[90] F. Brion, Y. Le Page, B. Piccini, O. Cardoso, S.K. Tong, B.C. Chung, O. Kah, Screening estrogenic activities of chemicals or mixtures in vivo using transgenic (cyp19a1bGFP) zebrafish embryos, PloS one 7 (2012) e36069.

[91] Y. Le Page, A. Menuet, O. Kah, F. Pakdel, Characterization of a cis-acting element involved in cell-specific expression of the zebrafish brain aromatase gene, Molecular reproduction and development 75 (2008) 1549-1557.

[92] P. Ekstrom, C.M. Johnsson, L.M. Ohlin, Ventricular proliferation zones in the brain of an adult teleost fish and their relation to neuromeres and migration (secondary matrix) zones, The Journal of comparative neurology 436 (2001) 92110.

[93] D. Kranz, W. Richter, [Autoradiographic studies on the localization of the matrix zones of the diencephalon of young and adult Lebistes reticulatus (Teleostae)], Zeitschrift fur mikroskopisch-anatomische Forschung 82 (1970) 42-66.

[94] V.D. Kranz, W. Richter, [Neurogenesis and regeneration in the brain of teleosts in relation to age. (Autoradiographic studies)], Zeitschrift fur Alternsforschung 30 (1975) 371-382. 
[95] B. Adolf, P. Chapouton, C.S. Lam, S. Topp, B. Tannhauser, U. Strahle, M. Gotz, L. Bally-Cuif, Conserved and acquired features of adult neurogenesis in the zebrafish telencephalon, Developmental biology 295 (2006) 278-293.

[96] P. Chapouton, R. Jagasia, L. Bally-Cuif, Adult neurogenesis in non-mammalian vertebrates, BioEssays : news and reviews in molecular, cellular and developmental biology 29 (2007) 745-757.

[97] P. Chapouton, P. Skupien, B. Hesl, M. Coolen, J.C. Moore, R. Madelaine, E. Kremmer, T. Faus-Kessler, P. Blader, N.D. Lawson, L. Bally-Cuif, Notch activity levels control the balance between quiescence and recruitment of adult neural stem cells, The Journal of neuroscience : the official journal of the Society for Neuroscience 30 (2010) 7961-7974.

[98] H. Grandel, J. Kaslin, J. Ganz, I. Wenzel, M. Brand, Neural stem cells and neurogenesis in the adult zebrafish brain: origin, proliferation dynamics, migration and cell fate, Developmental biology 295 (2006) 263-277.

[99] J. Kaslin, J. Ganz, M. Geffarth, H. Grandel, S. Hans, M. Brand, Stem cells in the adult zebrafish cerebellum: initiation and maintenance of a novel stem cell niche, The Journal of neuroscience : the official journal of the Society for Neuroscience 29 (2009) 6142-6153.

[100] M. Marz, P. Chapouton, N. Diotel, C. Vaillant, B. Hesl, M. Takamiya, C.S. Lam, O. Kah, L. Bally-Cuif, U. Strahle, Heterogeneity in progenitor cell subtypes in the ventricular zone of the zebrafish adult telencephalon, Glia 58 (2010) 870-888.

[101] I. Rothenaigner, M. Krecsmarik, J.A. Hayes, B. Bahn, A. Lepier, G. Fortin, M. Gotz, R. Jagasia, L. Bally-Cuif, Clonal analysis by distinct viral vectors identifies bona fide neural stem cells in the adult zebrafish telencephalon and characterizes their division properties and fate, Development 138 (2011) 1459-1469.

[102] G.K. Zupanc, Adult neurogenesis and neuronal regeneration in the brain of teleost fish, Journal of physiology, Paris 102 (2008) 357-373.

[103] N. Diotel, C. Vaillant, C. Gabbero, S. Mironov, A. Fostier, M.M. Gueguen, I. Anglade, O. Kah, E. Pellegrini, Effects of estradiol in adult neurogenesis and brain repair in zebrafish, Hormones and behavior 63 (2013) 193-207.

[104] K. Ampatzis, P. Makantasi, C.R. Dermon, Cell proliferation pattern in adult zebrafish forebrain is sexually dimorphic, Neuroscience 226 (2012) 367-381.

[105] O. Brock, M. Keller, A. Veyrac, Q. Douhard, J. Bakker, Short term treatment with estradiol decreases the rate of newly generated cells in the subventricular zone and main olfactory bulb of adult female mice, Neuroscience 166 (2010) 368-376.

[106] C.A. Mazzucco, S.E. Lieblich, B.I. Bingham, M.A. Williamson, V. Viau, L.A. Galea, Both estrogen receptor alpha and estrogen receptor beta agonists enhance cell proliferation in the dentate gyrus of adult female rats, Neuroscience 141 (2006) 1793-1800.

[107] B.K. Ormerod, T.T. Lee, L.A. Galea, Estradiol enhances neurogenesis in the dentate gyri of adult male meadow voles by increasing the survival of young granule neurons, Neuroscience 128 (2004) 645-654.

[108] L.M. Garcia-Segura, F. Naftolin, J.B. Hutchison, I. Azcoitia, J.A. Chowen, Role of astroglia in estrogen regulation of synaptic plasticity and brain repair, J Neurobiol 40 (1999) 574-584.

[109] K. Pettersson, J.A. Gustafsson, Role of estrogen receptor beta in estrogen action, Annu Rev Physiol 63 (2001) 165-192.

[110] G.K. Zupanc, R.F. Sirbulescu, Adult neurogenesis and neuronal regeneration in the central nervous system of teleost fish, Eur J Neurosci 34 (2011) 917-929. 
[111] E.V. Baumgart, J.S. Barbosa, L. Bally-Cuif, M. Gotz, J. Ninkovic, Stab wound injury of the zebrafish telencephalon: a model for comparative analysis of reactive gliosis, Glia 60 (2012) 343-357.

[112] M. Marz, R. Schmidt, S. Rastegar, U. Strahle, Regenerative response following stab injury in the adult zebrafish telencephalon, Dev Dyn 240 (2011) 2221-2231.

[113] E. Pellegrini, C. Vaillant, N. Diotel, P. Benquet, F. Brion, O. Kah, Expression, regulation and potential functions of aromatase in radial glial cells of the fish brainIn: Balthazart, J. Ball, Gregory F. eds. Brain aromatase, estrogens, and behavior, Oxford University Press, Oxford ; New York, 2013.

[114] X. Liu, P. Zhu, K.W. Sham, J.M. Yuen, C. Xie, Y. Zhang, Y. Liu, S. Li, X. Huang, C.H. Cheng, H. Lin, Identification of a membrane estrogen receptor in zebrafish with homology to mammalian GPER and its high expression in early germ cells of the testis, Biol Reprod 80 (2009) 1253-1261.

[115] P.L. Bardet, B. Horard, M. Robinson-Rechavi, V. Laudet, J.M. Vanacker, Characterization of oestrogen receptors in zebrafish (Danio rerio), Journal of molecular endocrinology 28 (2002) 153-163.

[116] G. Chandrasekar, A. Archer, J.A. Gustafsson, M. Andersson Lendahl, Levels of 17beta-estradiol receptors expressed in embryonic and adult zebrafish following in vivo treatment of natural or synthetic ligands, PloS one 5 (2010) e9678.

[117] K. Mouriec, J.J. Lareyre, S.K. Tong, Y. Le Page, C. Vaillant, E. Pellegrini, F. Pakdel, B.C. Chung, O. Kah, I. Anglade, Early regulation of brain aromatase (cyp19a1b) by estrogen receptors during zebrafish development, Developmental dynamics : an official publication of the American Association of Anatomists 238 (2009) 26412651.

[118] L.B. Griffin, K.E. January, K.W. Ho, K.A. Cotter, G.V. Callard, Morpholino-mediated knockdown of ERalpha, ERbetaa, and ERbetab mRNAs in zebrafish (Danio rerio) embryos reveals differential regulation of estrogen-inducible genes, Endocrinology 154 (2013) 4158-4169.

[119] M. Froehlicher, A. Liedtke, K. Groh, H. Lopez-Schier, S.C. Neuhauss, H. Segner, R.I. Eggen, Estrogen receptor subtype beta2 is involved in neuromast development in zebrafish (Danio rerio) larvae, Developmental biology 330 (2009) 32-43.

[120] Y. Shi, X. Liu, P. Zhu, J. Li, K.W. Sham, S.H. Cheng, S. Li, Y. Zhang, C.H. Cheng, H. Lin, G-protein-coupled estrogen receptor 1 is involved in brain development during zebrafish (Danio rerio) embryogenesis, Biochemical and biophysical research communications 435 (2013) 21-27.

[121] A.K. Hotchkiss, C.V. Rider, C.R. Blystone, V.S. Wilson, P.C. Hartig, G.T. Ankley, P.M. Foster, C.L. Gray, L.E. Gray, Fifteen years after "Wingspread"--environmental endocrine disrupters and human and wildlife health: where we are today and where we need to go, Toxicological sciences : an official journal of the Society of Toxicology 105 (2008) 235-259.

[122] K.A. Cotter, A. Yershov, A. Novillo, G.V. Callard, Multiple structurally distinct ERalpha mRNA variants in zebrafish are differentially expressed by tissue type, stage of development and estrogen exposure, General and comparative endocrinology 194 (2013) 217-229.

[123] N. Diotel, A. Servili, M.M. Gueguen, S. Mironov, E. Pellegrini, C. Vaillant, Y. Zhu, O. Kah, I. Anglade, Nuclear progesterone receptors are up-regulated by estrogens in neurons and radial glial progenitors in the brain of zebrafish, PloS one 6 (2011) e28375. 
[124] M. Vosges, O. Kah, N. Hinfray, E. Chadili, Y. Le Page, Y. Combarnous, J.M. Porcher, F. Brion, 17alpha-Ethinylestradiol and nonylphenol affect the development of forebrain GnRH neurons through an estrogen receptors-dependent pathway, Reproductive toxicology 33 (2012) 198-204.

[125] M. Vosges, Y. Le Page, B.C. Chung, Y. Combarnous, J.M. Porcher, O. Kah, F. Brion, 17alpha-ethinylestradiol disrupts the ontogeny of the forebrain GnRH system and the expression of brain aromatase during early development of zebrafish, Aquatic toxicology 99 (2010) 479-491.

[126] W.K. Tse, B.H. Yeung, H.T. Wan, C.K. Wong, Early embryogenesis in zebrafish is affected by bisphenol A exposure, Biology open 2 (2013) 466-471.

[127] C.A. Staples, P.B. Dorn, G.M. Klecka, S.T. O'Block, D.R. Branson, L.R. Harris, Bisphenol A concentrations in receiving waters near US manufacturing and processing facilities, Chemosphere 40 (2000) 521-525.

[128] X. Wang, Q. Dong, Y. Chen, H. Jiang, Q. Xiao, Y. Wang, W. Li, C. Bai, C. Huang, D. Yang, Bisphenol A affects axonal growth, musculature and motor behavior in developing zebrafish, Aquatic toxicology 142-143 (2013) 104-113.

[129] S.H. Lam, M.M. Hlaing, X. Zhang, C. Yan, Z. Duan, L. Zhu, C.Y. Ung, S. Mathavan, C.N. Ong, Z. Gong, Toxicogenomic and phenotypic analyses of bisphenol-A early-life exposure toxicity in zebrafish, PloS one 6 (2011) e28273.

[130] Y. Gibert, S. Sassi-Messai, J.B. Fini, L. Bernard, D. Zalko, J.P. Cravedi, P. Balaguer, M. Andersson-Lendahl, B. Demeneix, V. Laudet, Bisphenol A induces otolith malformations during vertebrate embryogenesis, BMC developmental biology 11 (2011) 4.

[131] K.S. Saili, M.M. Corvi, D.N. Weber, A.U. Patel, S.R. Das, J. Przybyla, K.A. Anderson, R.L. Tanguay, Neurodevelopmental low-dose bisphenol A exposure leads to early life-stage hyperactivity and learning deficits in adult zebrafish, Toxicology 291 (2012) 83-92.

[132] A. Riu, C.W. McCollum, C.L. Pinto, M. Grimaldi, A. Hillenweck, E. Perdu, D. Zalko, L. Bernard, V. Laudet, P. Balaguer, M. Bondesson, J.A. Gustafsson, Halogenated bisphenol-A analogs act as obesogens in zebrafish larvae (Danio rerio), Toxicol Sci 139 (2014) 48-58.

[133] J. Iwabuchi, K. Koshimizu, T. Nakagawa, Expression profile of the aromatase enzyme in the Xenopus brain and localization of estradiol and estrogen receptors in each tissue, General and comparative endocrinology 194 (2013) 286-294.

[134] J.S. Lee, K. Iwabuchi, K. Nomaru, N. Nagahama, E.Y. Kim, H. Iwata, Molecular and functional characterization of a novel aryl hydrocarbon receptor isoform, AHR1beta, in the chicken (Gallus gallus), Toxicological sciences : an official journal of the Society of Toxicology 136 (2013) 450-466.

[135] J. Iwabuchi, K. Arai, S. Miyata, Isolation of novel isoforms of estrogen receptor genes from Xenopus gonad and brain, Zoological science 25 (2008) 1227-1233.

[136] S. Fumino, N. Iwai, E. Deguchi, O. Kimura, S. Ono, T. Iwabuchi, Estrogen receptor expression in anomalous arrangement of the pancreaticobiliary duct, Journal of pediatric surgery 40 (2005) 1716-1720.

[137] M. Takase, T. Iguchi, Molecular cloning of two isoforms of Xenopus (Silurana) tropicalis estrogen receptor mRNA and their expression during development, Biochimica et biophysica acta 1769 (2007) 172-181.

[138] K.H. Wu, M.L. Tobias, D.B. Kelley, Estrogen receptor expression in laryngeal muscle in relation to estrogen-dependent increases in synapse strength, Neuroendocrinology 78 (2003) 72-80. 
[139] P. Duarte-Guterman, M.J. Ryan, N.S. Hogan, V.L. Trudeau, Developmental profiles and thyroid hormone regulation of brain transcripts in frogs: a species comparison with emphasis on Physalaemus pustulosus, Brain, behavior and evolution 79 (2012) 98-112.

[140] M. Chakraborty, S.S. Burmeister, Sexually dimorphic androgen and estrogen receptor mRNA expression in the brain of tungara frogs, Hormones and behavior 58 (2010) 619-627.

[141] G.A. Davis, F.L. Moore, Neuroanatomical distribution of androgen and estrogen receptor-immunoreactive cells in the brain of the male roughskin newt, The Journal of comparative neurology 372 (1996) 294-308.

[142] G. Guerriero, C.E. Roselli, M. Paolucci, V. Botte, G. Ciarcia, Estrogen receptors and aromatase activity in the hypothalamus of the female frog, Rana esculenta. Fluctuations throughout the reproductive cycle, Brain research 880 (2000) 92101.

[143] J.L. Do Rego, J.Y. Seong, D. Burel, V. Luu-The, D. Larhammar, K. Tsutsui, G. Pelletier, M.C. Tonon, H. Vaudry, Steroid biosynthesis within the frog brain: a model of neuroendocrine regulation, Annals of the New York Academy of Sciences 1163 (2009) 83-92.

[144] A.G. Mensah-Nyagan, J.L. Do-Rego, D. Beaujean, V. Luu-The, G. Pelletier, H. Vaudry, Regulation of neurosteroid biosynthesis in the frog diencephalon by GABA and endozepines, Hormones and behavior 40 (2001) 218-225.

[145] H. Vaudry, J.L. Do Rego, D. Burel, V. Luu-The, G. Pelletier, D. Vaudry, K. Tsutsui, Neurosteroid biosynthesis in the brain of amphibians, Frontiers in endocrinology 2 (2011) 79.

[146] J. Iwabuchi, S. Wako, T. Tanaka, A. Ishikawa, Y. Yoshida, S. Miyata, Analysis of the p450 aromatase gene expression in the Xenopus brain and gonad, The Journal of steroid biochemistry and molecular biology 107 (2007) 149-155.

[147] S. Kuntz, A. Chesnel, S. Flament, D. Chardard, Cerebral and gonadal aromatase expressions are differently affected during sex differentiation of Pleurodeles waltl, Journal of molecular endocrinology 33 (2004) 717-727.

[148] V.S. Langlois, A.C. Carew, B.D. Pauli, M.G. Wade, G.M. Cooke, V.L. Trudeau, Low levels of the herbicide atrazine alter sex ratios and reduce metamorphic success in Rana pipiens tadpoles raised in outdoor mesocosms, Environmental health perspectives 118 (2010) 552-557.

[149] V.S. Langlois, P. Duarte-Guterman, V.L. Trudeau, Expression profiles of reproduction- and thyroid hormone-related transcripts in the brains of chemically-induced intersex frogs, Sexual development : genetics, molecular biology, evolution, endocrinology, embryology, and pathology of sex determination and differentiation 5 (2011) 26-32.

[150] R. Urbatzka, I. Lutz, W. Kloas, Aromatase, steroid-5-alpha-reductase type 1 and type 2 mRNA expression in gonads and in brain of Xenopus laevis during ontogeny, General and comparative endocrinology 153 (2007) 280-288.

[151] S. Kuntz, D. Chardard, A. Chesnel, M. Ducatez, M. Callier, S. Flament, Expression of aromatase and steroidogenic factor 1 in the lung of the urodele amphibian Pleurodeles waltl, Endocrinology 145 (2004) 3111-3114.

[152] P. Coumailleau, O. Kah, Cyp19a1 (Aromatase) Expression in the Xenopus Brain at Different Developmental Stages, Journal of neuroendocrinology 26 (2014) 226236. 
[153] L. Burrone, A. Santillo, C. Pinelli, G.C. Baccari, M.M. Di Fiore, Induced synthesis of P450 aromatase and 17beta-estradiol by D-aspartate in frog brain, The Journal of experimental biology 215 (2012) 3559-3565.

[154] T. Nakagawa, J. Iwabuchi, Brain-specific promoter/exon I.f of the cyp19a1 (aromatase) gene in Xenopus laevis, The Journal of steroid biochemistry and molecular biology 132 (2012) 247-255.

[155] S. Miyata, T. Kubo, In vitro effects of estradiol and aromatase inhibitor treatment on sex differentiation in Xenopus laevis gonads, General and comparative endocrinology 119 (2000) 105-110.

[156] G. Okada, K. Maruo, S. Funada, M. Nakamura, Differential display analysis of gene expression in female-to-male sex-reversing gonads of the frog Rana rugosa, General and comparative endocrinology 155 (2008) 623-634.

[157] I. Villalpando, H. Merchant-Larios, Determination of the sensitive stages for gonadal sex-reversal in Xenopus laevis tadpoles, The International journal of developmental biology 34 (1990) 281-285.

[158] T.B. Hayes, Sex determination and primary sex differentiation in amphibians: genetic and developmental mechanisms, The Journal of experimental zoology 281 (1998) 373-399.

[159] C.A. Mackenzie, M. Berrill, C. Metcalfe, B.D. Pauli, Gonadal differentiation in frogs exposed to estrogenic and antiestrogenic compounds, Environmental toxicology and chemistry / SETAC 22 (2003) 2466-2475.

[160] W. Kloas, Amphibians as a model for the study of endocrine disruptors, International review of cytology 216 (2002) 1-57.

[161] N.S. Hogan, P. Duarte, M.G. Wade, D.R. Lean, V.L. Trudeau, Estrogenic exposure affects metamorphosis and alters sex ratios in the northern leopard frog (Rana pipiens): identifying critically vulnerable periods of development, General and comparative endocrinology 156 (2008) 515-523.

[162] L. Szymanski, J. Bakker, Aromatase knockout mice show normal steroid-induced activation of gonadotrophin-releasing hormone neurones and luteinising hormone surges with a reduced population of kisspeptin neurones in the rostral hypothalamus, Journal of neuroendocrinology 24 (2012) 1222-1233.

[163] W. Kloas, R. Urbatzka, R. Opitz, S. Wurtz, T. Behrends, B. Hermelink, F. Hofmann, O. Jagnytsch, H. Kroupova, C. Lorenz, N. Neumann, C. Pietsch, A. Trubiroha, C. Van Ballegooy, C. Wiedemann, I. Lutz, Endocrine disruption in aquatic vertebrates, Annals of the New York Academy of Sciences 1163 (2009) 187-200.

[164] A. Cevasco, R. Urbatzka, S. Bottero, A. Massari, F. Pedemonte, W. Kloas, A. Mandich, Endocrine disrupting chemicals (EDC) with (anti)estrogenic and (anti)androgenic modes of action affecting reproductive biology of Xenopus laevis: II. Effects on gonad histomorphology, Comparative biochemistry and physiology. Toxicology \& pharmacology : CBP 147 (2008) 241-251.

[165] A.R. Tompsett, S. Wiseman, E. Higley, J.P. Giesy, M. Hecker, Effects of exposure to 17alpha-ethynylestradiol during larval development on growth, sexual differentiation, and abundances of transcripts in the liver of the wood frog (Lithobates sylvaticus), Aquatic toxicology 126 (2013) 42-51.

[166] P. Duarte-Guterman, L. Navarro-Martin, V.L. Trudeau, Mechanisms of crosstalk between endocrine systems: Regulation of sex steroid hormone synthesis and action by thyroid hormones, General and comparative endocrinology (2014). 
[167] V. Martinez-Cerdeno, S.C. Noctor, A.R. Kriegstein, Estradiol stimulates progenitor cell division in the ventricular and subventricular zones of the embryonic neocortex, The European journal of neuroscience 24 (2006) 3475-3488.

[168] S. Ijiri, C. Berard, J.M. Trant, Characterization of gonadal and extra-gonadal forms of the cDNA encoding the Atlantic stingray (Dasyatis sabina) cytochrome P450 aromatase (CYP19), Molecular and cellular endocrinology 164 (2000) 169-181.

[169] S. Ijiri, Y. Kazeto, P.M. Lokman, S. Adachi, K. Yamauchi, Characterization of a cDNA encoding P-450 aromatase (CYP19) from Japanese eel ovary and its expression in ovarian follicles during induced ovarian development, General and comparative endocrinology 130 (2003) 193-203.

[170] S.R. Jeng, S. Dufour, C.F. Chang, Differential expression of neural and gonadal aromatase enzymatic activities in relation to gonadal development in Japanese eel, Anguilla japonica, Journal of experimental zoology. Part A, Comparative experimental biology 303 (2005) 802-812.

[171] S.R. Jeng, J. Pasquier, W.S. Yueh, G.R. Chen, Y.H. Lee, S. Dufour, C.F. Chang, Differential regulation of the expression of cytochrome P450 aromatase, estrogen and androgen receptor subtypes in the brain-pituitary-ovarian axis of the Japanese eel (Anguilla japonica) reveals steroid dependent and independent mechanisms, General and comparative endocrinology 175 (2012) 163-172.

[172] C.V. Henkel, E. Burgerhout, D.L. de Wijze, R.P. Dirks, Y. Minegishi, H.J. Jansen, H.P. Spaink, S. Dufour, F.A. Weltzien, K. Tsukamoto, G.E. van den Thillart, Primitive duplicate Hox clusters in the European eel's genome, PloS one 7 (2012) e32231.

[173] K.M. Choi, J.Y. Kim, Y. Kim, Distribution of the Immunoreactivity for Glycoprotein M6B in the Neurogenic Niche and Reactive Glia in the Injury Penumbra Following Traumatic Brain Injury in Mice, Experimental neurobiology 22 (2013) 277-282.

[174] Y. Goldshmit, F. Frisca, A.R. Pinto, A. Pebay, J.K. Tang, A.L. Siegel, J. Kaslin, P.D. Currie, Fgf2 improves functional recovery-decreasing gliosis and increasing radial glia and neural progenitor cells after spinal cord injury, Brain and behavior 4 (2014) 187-200.

[175] Y. Guo, Q. Wei, Y. Huang, W. Xia, Y. Zhou, S. Wang, The effects of astrocytes on differentiation of neural stem cells are influenced by knock-down of the glutamate transporter, GLT-1, Neurochemistry international 63 (2013) 498-506.

[176] B. Saha, S. Peron, K. Murray, M. Jaber, A. Gaillard, Cortical lesion stimulates adult subventricular zone neural progenitor cell proliferation and migration to the site of injury, Stem cell research 11 (2013) 965-977.

[177] M.R. Costa, M. Gotz, B. Berninger, What determines neurogenic competence in glia?, Brain research reviews 63 (2010) 47-59. 


\section{Legends to figures:}

Figure 1 (A-L): Expression of esr2a on a series of transverse sections of the telencephalon and preoptic area in an adult male (A-F) and female zebrafish (G-L) as shown by radioactive in situ hybridization. Note that the highest expression is detected in the preoptic area (BC) and the ventral hypothalamus (J). However, lower expression is observable in many other regions, in particular along the brain ventricles and their recessi (arrows). Bar $=100 \mu \mathrm{m}$

ATN: anterior tuberal nucleus; CA: anterior commissure; Cpop: Postoptic commissure; CM: Corpius mammilaris; CO: optic chiasma; CP: Posterior commissure; Dc: central zone of dorsal telencephalic area; DI: lateral zone of dorsal telencephalic area; Dm, medial zone of dorsal telencephalic area; Dp: posterior zone of dorsal telencephalic area; Hav: ventral habenular nucleus; Hc: central zone of periventricular hypothalamus; Hv: ventral zone of periventricular hypothalamus; MT: Midbrain tegmentum; OT: Optic tract; PGa: anterior preglomerular nucleus; PGI, lateral preglomerular nucleus; PGm: medial preglomerular nucleus; PPa: parvocellular preoptic nucleus, anterior part; PPp: parvocellular preoptic nucleus, posterior part; PTN: posterior tuberal nucleus; RL: lateral recess; RP: Posterior recess; SC: Suprachiasmatic nucleus; TeO: Optic tectum; TLa: torus lateralis; TPp: periventricular nucleus of posterior tuberculum; Vd: dorsal nucleus of dorsal telencephalic area; Vv: ventral nucleus of dorsal telencephalic area; VM: ventromedial thalamic nucleus; VI: lateral nucleus of dorsal telencephalic area; ZI: zona limitans.

Figure 2: Aromatase B-positive cells in the brain of zebrafish exhibit active proliferation. Example of aromatase $B$ positive cells $(A)$ at the level of the nucleus recessi posterioris (NRP) surrounding the posterior recess (rp) of the third ventricle (III). (B) shows that 24 hours after BrdU exposure, BrdU-positive nuclei are visible at the level of the NRP and correspond to the nuclei of aromatase B positive cells as shown in (C) (arrowheads). Bar $=50 \mu \mathrm{m}$.

Figure 3: Schematic representation of aromatase positive-cells RGCs (green cells) in the brain of zebrafish. RGCs can proliferate and generate neuroblasts (red cells) that migrate along the radial processes and give birth to neurons (orange cells. RGCs can produce estrogens that can either act on neighboring neurons or on RGC themselves 
to modulate their neurogenic activity. RGCs are also target for peripheral steroids and xeno-hormones.

Figure 4: Summary of the known characteristics of cyp19a1 genes in vertebrates 

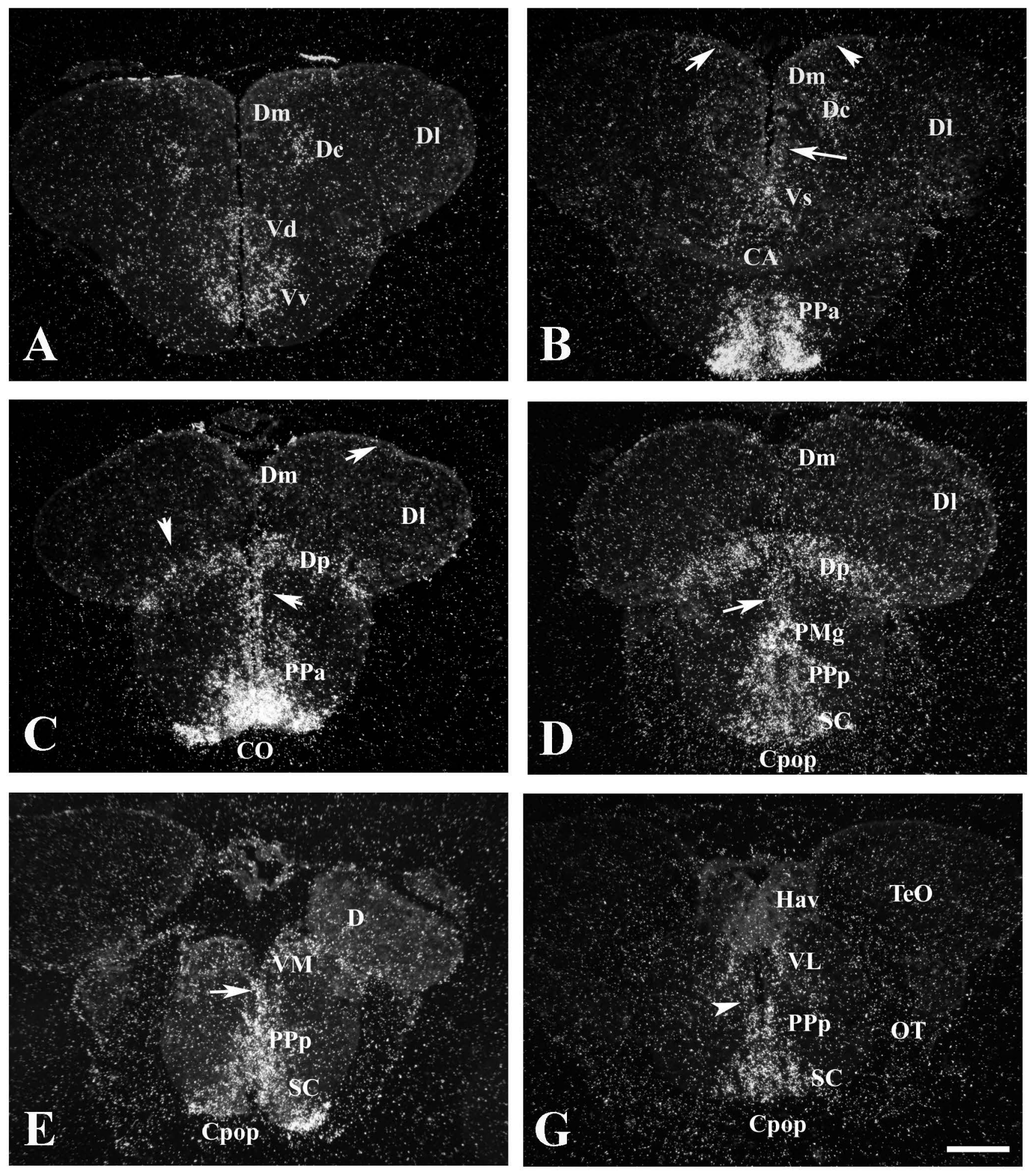

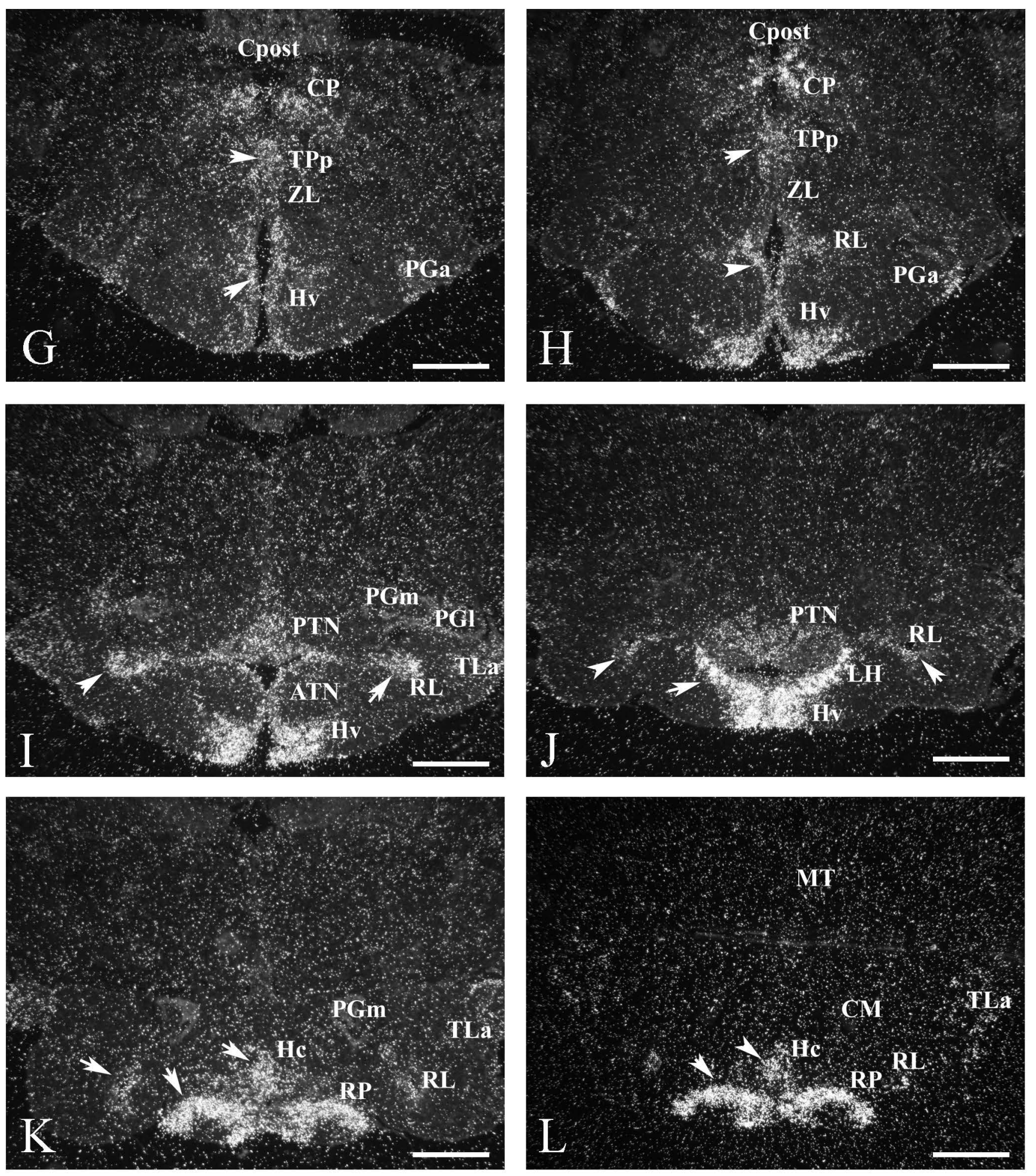

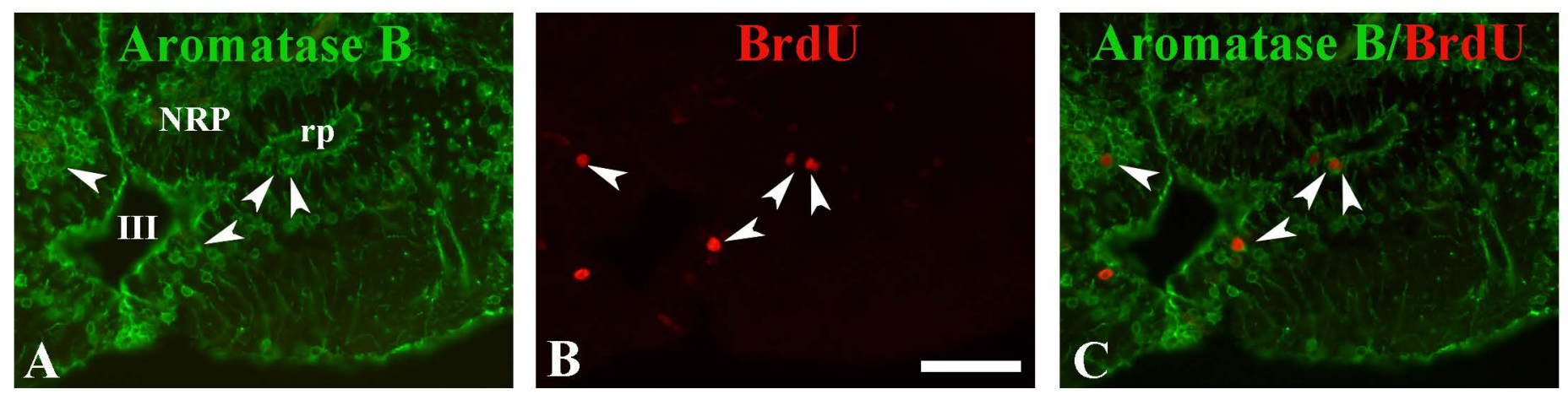


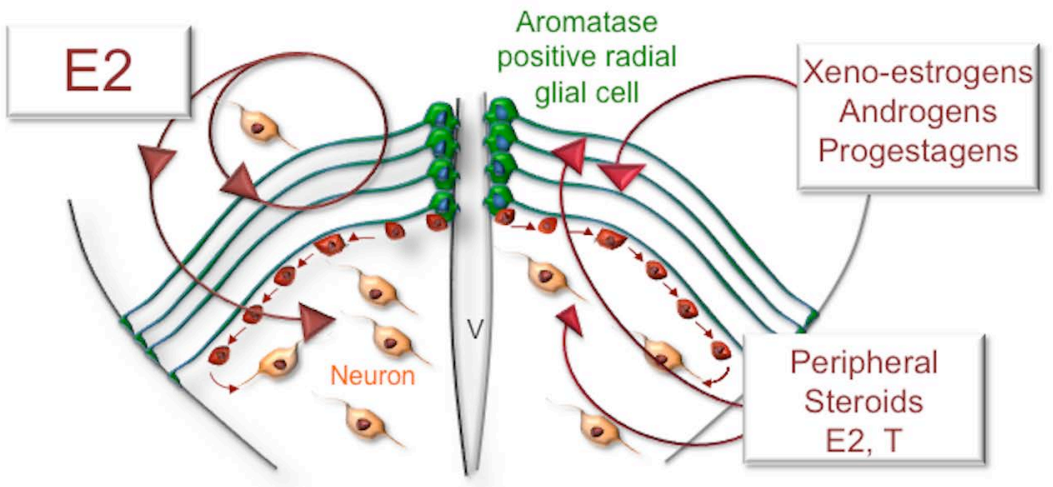




\section{Crown teleosts}

2 cyp19a1 genes

Aromatase B expressed in RGCs

No expression of aromatase in neurons High adult neurogenic activity Strong brain repair capacity Hermaphroditism: YES

Basal teleost: eels 1 cyp19a1 gene Aromatase B expressed in radial glia No expression of aromatase in neurons Sexual plasticity?

Basal actinopterygians 1 cyp19a1 gene Brain expression unknown?

\section{Tetrapods}

1 cyp19a1 gene

Aromatase expressed in neurons Low adult neurogenic activity Weak brain repair capacity Hermaphroditism: NO

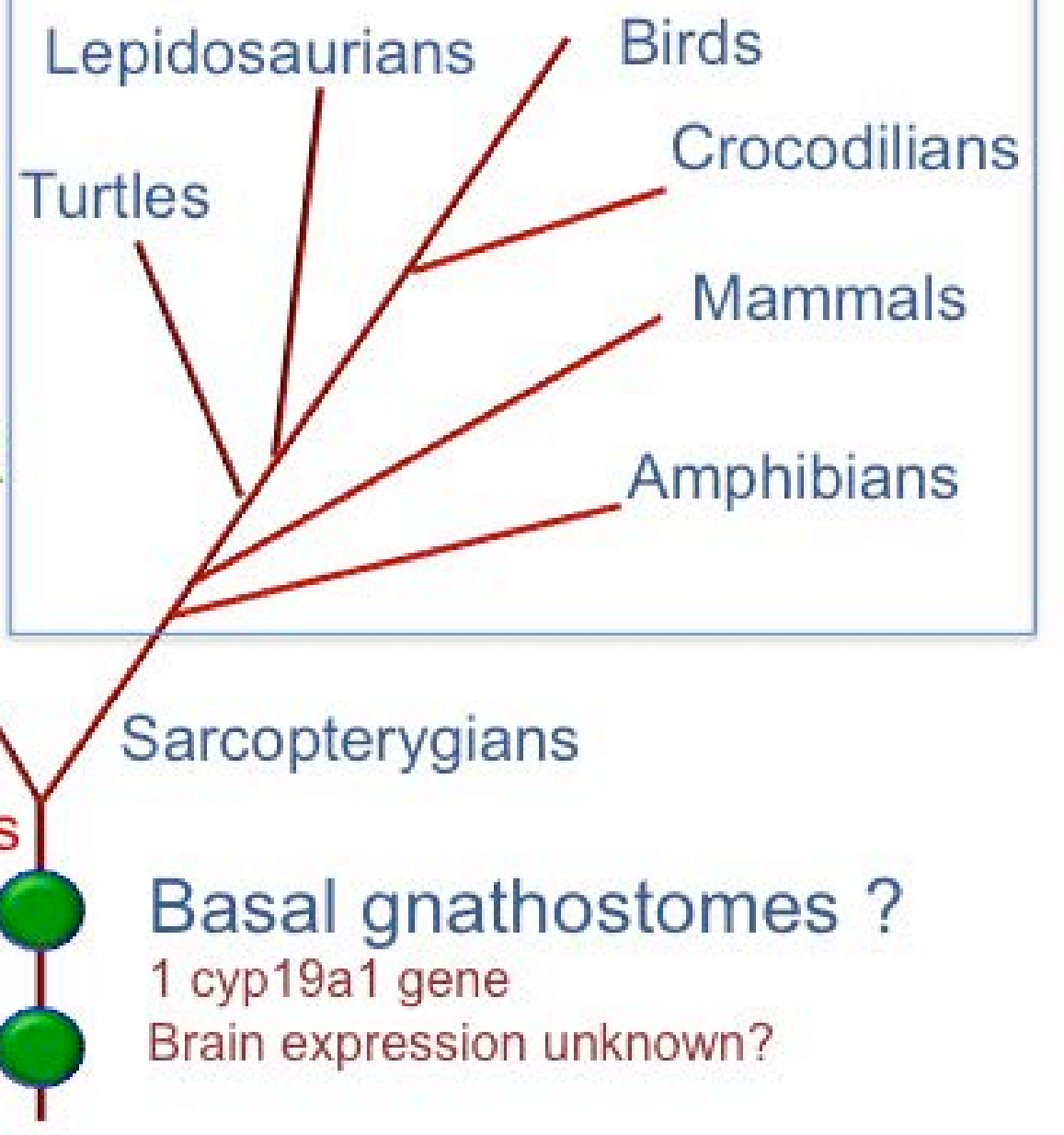

